\title{
Dynamics of Phosphoinositide-Dependent Signaling in Sympathetic Neurons
}

\author{
๑Dartin Kruse, ${ }^{1 \star}$ Oscar Vivas, ${ }^{1 \star}$ Alexis Traynor-Kaplan, ${ }^{2}$ and ${ }^{-B}$ Bertil Hille ${ }^{1}$ \\ ${ }^{1}$ Department of Physiology and Biophysics, University of Washington, Seattle, Washington 98195, and ${ }^{2}$ ATK Innovation, Analytics and Discovery, North \\ Bend, Washington 98045
}

In neurons, loss of plasma membrane phosphatidylinositol 4,5-bisphosphate $\left[\mathrm{PI}(4,5) \mathrm{P}_{2}\right]$ leads to a decrease in exocytosis and changes in electrical excitability. Restoration of $\mathrm{PI}(4,5) \mathrm{P}_{2}$ levels after phospholipase $\mathrm{C}$ activation is therefore essential for a return to basal neuronal activity. However, the dynamics of phosphoinositide metabolism have not been analyzed in neurons. We measured dynamic changes of $\mathrm{PI}(4,5) \mathrm{P}_{2}$, phosphatidylinositol 4-phosphate, diacylglycerol, inositol 1,4,5-trisphosphate, and $\mathrm{Ca}^{2+}$ upon muscarinic stimulation in sympathetic neurons from adult male Sprague-Dawley rats with electrophysiological and optical approaches. We used this kinetic information to develop a quantitative description of neuronal phosphoinositide metabolism. The measurements and analysis show and explain faster synthesis of $\mathrm{PI}(4,5) \mathrm{P}_{2}$ in sympathetic neurons than in electrically nonexcitable tsA201 cells. They can be used to understand dynamic effects of receptor-mediated phospholipase $\mathrm{C}$ activation on excitability and other $\mathrm{PI}(4,5) \mathrm{P}_{2}$-dependent processes in neurons.

Key words: excitability; M-current; phosphoinositide metabolism; $\mathrm{PI}(4,5) \mathrm{P}_{2}$; superior cervical ganglion neurons

\section{Significance Statement}

Phosphatidylinositol 4,5-bisphosphate $\left[\mathrm{PI}(4,5) \mathrm{P}_{2}\right]$ is a minor phospholipid in the cytoplasmic leaflet of the plasma membrane. Depletion of $\mathrm{PI}(4,5) \mathrm{P}_{2}$ via phospholipase C-mediated hydrolysis leads to a decrease in exocytosis and alters electrical excitability in neurons. Restoration of $\mathrm{PI}(4,5) \mathrm{P}_{2}$ is essential for a return to basal neuronal activity. However, the dynamics of phosphoinositide metabolism have not been analyzed in neurons. We studied the dynamics of phosphoinositide metabolism in sympathetic neurons upon muscarinic stimulation and used the kinetic information to develop a quantitative description of neuronal phosphoinositide metabolism. The measurements and analysis show a several-fold faster synthesis of $\mathrm{PI}(4,5) \mathrm{P}_{2}$ in sympathetic neurons than in an electrically nonexcitable cell line, and provide a framework for future studies of $\mathrm{PI}(4,5) \mathrm{P}_{2}$-dependent processes in neurons.

\section{Introduction}

We report the dynamics of phosphoinositide metabolism and signaling in single living neurons. We measure receptor-induced

Received Sept. 22, 2015; revised Dec. 11, 2015; accepted Dec. 22, 2015.

Author contributions: M.K., O.V., and B.H. designed research; M.K., O.V., and A.T.-K. performed research; M.K., O.V., and A.T.-K. analyzed data; M.K., O.V., and B.H. wrote the paper.

This work was supported by the National Institute of Neurological Disorders and Stroke of the NIH (R37NS008174), the Wayne E. Crill Endowed Professorship, and an Alexander von Humboldt-Foundation fellowship (M.K.); The Virtual Cell is supported by NIH Grant P41 GM103313 from the National Institute for General Medical Sciences; we appreciate use of the Mass Spectrometry Center of the School of Pharmacy. We thank Drs. Eamonn J. Dickson, Jill B. Jensen, Seung R. Jung, Duk-Su Koh, Jong B. Seo, and Haijie Yu for reading the paper; Gucan Dai, Eamonn Dickson, and Dale Whittington for help with establishing mass spectrometry experiments; Jennifer Deem and Stanley McKnight for experimental advice with $\mathrm{IP}_{3} \mathrm{R}$ Western blot analysis; Mika Munari for help with plasmid purification; all members of the Hille laboratory and colleagues in the Department of Physiology and Biophysics at the University of Washington for discussions and experimental advice; and Lea M. Miller for technical help.

The authors declare no competing financial interests.

*M.K. and O.V. contributed equally to this work.

Correspondence should be addressed to Dr. Bertil Hille, Department of Physiology and Biophysics, University of Washington School of Medicine, Box 357290, Seattle, WA 98195-7290. E-mail: hille@u.washington.edu.

DOI:10.1523/JNEUROSCI.3535-15.2016

Copyright $\odot 2016$ the authors $\quad 0270-6474 / 16 / 361386-15 \$ 15.00 / 0$ changes of phosphatidylinositol 4,5-bisphosphate $\left[\mathrm{PI}(4,5) \mathrm{P}_{2}\right]$, phosphatidylinositol 4-phosphate $[\mathrm{PI}(4) \mathrm{P}]$, inositol 1,4,5-trisphosphate $\left(\mathrm{IP}_{3}\right)$, diacylglycerol (DAG), and $\mathrm{Ca}^{2+}$ and develop a kinetic description. Phosphoinositides are fundamental signaling components of all cellular membranes. $\mathrm{PI}(4,5) \mathrm{P}_{2}$ located at the plasma membrane is required by many membrane proteins to fulfill their functions. In neurons, binding of SNARE proteins and synaptotagmin to $\mathrm{PI}(4,5) \mathrm{P}_{2}$ allows vesicle docking and secretion (Di Paolo and De Camilli, 2006; Martin, 2015). Similarly, endocytosis (Cremona and De Camilli, 2001; Posor et al., 2015), actin filament assembly (Saarikangas et al., 2010), and ion channel activity (Hille et al., 2015) are regulated by $\mathrm{PI}(4,5) \mathrm{P}_{2}$.

$\mathrm{PI}(4,5) \mathrm{P}_{2}$ levels can be reduced through activation of receptors. Phospholipase C (PLC) activated by G-protein-coupled receptors and receptor tyrosine kinases cleave $\mathrm{PI}(4,5) \mathrm{P}_{2}$ into $\mathrm{IP}_{3}$ and DAG, activating several signaling pathways (Michell, 1975; Berridge and Irvine, 1984). At least 80 types of PLC-coupled receptors are known (Pawson et al., 2014). Receptor tyrosine kinases acting through PI 3-kinases also use $\mathrm{PI}(4,5) \mathrm{P}_{2}$ as a pre- 
cursor to synthesize $\mathrm{PI}(3,4,5) \mathrm{P}_{3}$. Once the stimulus activating these receptors is gone, $\mathrm{PI}(4,5) \mathrm{P}_{2}$ levels are restored (Willars et al., 1998; Cantley, 2002). $\mathrm{PI}(4,5) \mathrm{P}_{2}$ is synthesized in two steps involving sequential phosphorylation of phosphatidylinositol (PI) and PI(4)P by the action of lipid 4- and 5-kinases, respectively. The kinase steps are opposed by lipid phosphatases that convert $\mathrm{PI}(4,5) \mathrm{P}_{2}$ back to $\mathrm{PI}(4) \mathrm{P}$ (5-phosphatase) and $\mathrm{PI}(4) \mathrm{P}$ to PI (4-phosphatase). Biochemical experiments show that the PI pool is by far the largest, comprising $90-96 \%$ of the total phosphoinositide, whereas $\mathrm{PI}(4) \mathrm{P}$ and $\mathrm{PI}(4,5) \mathrm{P}_{2}$ make up much of the remainder (Willars et al., 1998; Xu et al., 2003), suggesting that primarily $\mathrm{PI}(4) \mathrm{P}$ levels limit $\mathrm{PI}(4,5) \mathrm{P}_{2}$ synthesis.

In a scenario where neuromodulators are released from extrasynaptic or synaptic sites to bathe nearby neurons, the activation of PLC and subsequent hydrolysis of $\mathrm{PI}(4,5) \mathrm{P}_{2}$ will arrest $\mathrm{PI}(4,5) \mathrm{P}_{2}$-dependent processes. For example, in superior cervical ganglion (SCG) neurons a voltage-gated potassium channel can be turned off by PLC-mediated hydrolysis of $\mathrm{PI}(4,5) \mathrm{P}_{2}$ (Brown and Adams, 1980; Suh and Hille, 2002; Zhang et al., 2003; Winks et al., 2005). This greatly increases the excitability of SCG neurons, facilitating firing of spikes while $\mathrm{PI}(4,5) \mathrm{P}_{2}$ is low, a process that in the CNS would be akin to arousal. Despite the importance of $\mathrm{PI}(4,5) \mathrm{P}_{2}$ resynthesis for the duration of such neuronal arousal, relatively little is known about the dynamics of $\mathrm{PI}(4,5) \mathrm{P}_{2}$ replenishment in neurons.

The dynamics of $\mathrm{PI}(4,5) \mathrm{P}_{2}$ synthesis have been measured carefully in several cell lines (Willars et al., 1998; Xu et al., 2003; Jensen et al., 2009; Falkenburger et al., 2010a,b). After depletion by $\mathrm{PLC}, 63 \%$ of $\mathrm{PI}(4,5) \mathrm{P}_{2}$ is resynthesized within $120 \mathrm{~s}$ in these cells. Similarly in neurons, $\mathrm{PI}(4,5) \mathrm{P}_{2}$ is depleted and resynthesized after PLC activation (Micheva et al., 2001; Winks et al., 2005). Although the kinetics of $\mathrm{PI}(4,5) \mathrm{P}_{2}$ depletion have been characterized and modeled for sympathetic neurons (Winks et al., 2005), we still lack a quantitative description of the underlying dynamics of $\mathrm{PI}(4,5) \mathrm{P}_{2}$ resynthesis.

We ask the following questions: how long does it take for a neuron to replenish the pool of $\mathrm{PI}(4,5) \mathrm{P}_{2}$ at the plasma membrane? How do these dynamics compare with other cells, and how are they regulated? We decided to study these questions in superior cervical ganglion neurons as the expression of $\mathrm{PI}(4,5) \mathrm{P}_{2}$-dependent ion channels and PLC-activating G-protein-coupled receptors are well described in these cells, thus making them an ideal model system to characterize the phosphoinositide metabolism of a primary neuron. Our results show a several-fold faster phosphoinositide metabolism in SCG neurons compared with nonexcitable cell lines, leading us to the hypothesis that $\mathrm{PI}(4,5) \mathrm{P}_{2}$ dynamics are cell-type-specific and that neurons use faster kinetics of $\mathrm{PI}(4,5) \mathrm{P}_{2}$ synthesis to fine-tune electrical excitability and other $\mathrm{PI}(4,5) \mathrm{P}_{2}$-dependent processes. We develop a quantitative framework for the dynamics of physiological processes in neurons that depend on $\mathrm{PI}(4,5) \mathrm{P}_{2}$.

\section{Materials and Methods}

Cells. Animals were handled according to guidelines of the University of Washington Institutional Animal Care and Use Committee. Neurons were isolated from SCG of adult (7- to 12-week-old) male SpragueDawley rats by enzymatic digestion as described previously (Beech et al., 1991; Vivas et al., 2013). Isolated neurons were plated on poly-L-lysine (Sigma-Aldrich)-coated glass chips and incubated in $5 \% \mathrm{CO}_{2}$ at $37^{\circ} \mathrm{C}$ in medium supplemented with $10 \%$ fetal bovine serum.

SCG neurons were transfected by nuclear injection $24 \mathrm{~h}$ after isolation using an Eppendorf 5242 pressure microinjector and 5171 micromanipulator system (Eppendorf). cDNA was dissolved in $1 \mathrm{mg} / \mathrm{ml}$ dextranfluorescein solution $(10,000 \mathrm{kDa}$; Molecular Probes) to yield a final concentration of $50-150 \mathrm{ng} / \mu \mathrm{l}$ of DNA and microinjected into the nu- cleus for $0.3 \mathrm{~s}$ at pressures of $80-120 \mathrm{hPa}$. TsA201 cells were cultured and transfected as described previously (Jensen et al., 2009). The following plasmids were used: TubbyR332H-YFP (provided by A. Tinker, University College of London, London, United Kingdom); human eCFP-PH (PLC $\delta 1$ ), eYFP-PH (PLC $\delta 1$ ), and CAAX-CFP (from K-Ras, provided by K. Jalink, The Netherlands Cancer Institute, Amsterdam, Netherlands); C1-YFP (from the C1 domain of PKC $\gamma$, provided by T. Meyer, Stanford University, Stanford, CA); the zebrafish voltage-sensitive phosphatase (Dr-VSP; provided by Y. Okamura, Osaka University, Osaka, Japan); and the $\mathrm{IP}_{3}$ LIBRA version III (LIBRAvIII; provided by A. Tanimura, Health Sciences University of Hokkaido, Tobetsu, Japan).

Electrophysiology. The potassium current $\mathrm{I}_{\mathrm{KCNQ} 2 / 3}$ was recorded in whole-cell configuration as previously described for SCG neurons (Vivas et al., 2014) and tsA201 cells (Falkenburger et al., 2010b).

Lipid analysis by mass spectrometry. Lipid analysis was a modification of previously described methods (Clark et al., 2011; Laketa et al., 2014). Each lipid determination required two sympathetic ganglia or the cultured cells from one $35 \mathrm{~mm} \sim 70 \%$ confluent dish. Briefly, pairs of ganglia were mechanically minced, and neurons and tsA201 cells were pelleted by centrifugation for $3 \mathrm{~min}$ at $1000 \times g$ and $4^{\circ} \mathrm{C}$. Cell pellets were resuspended in water. Lipids were first extracted twice with $\mathrm{N}$-butanol, followed by three extractions with chloroform. All extraction steps were performed on ice, and separation of aqueous and organic phases was achieved by centrifugation for $3 \mathrm{~min}$ at $20,000 \times g$ and $4^{\circ} \mathrm{C}$. Extracts were combined and solvents were evaporated under nitrogen. Lipids were methylated with (trimethlysilyl)diazomethane for $1 \mathrm{~h}$ at room temperature with suitable precautions. Lipids were separated by ultrahighpressure liquid chromatography (Acquity UPLC Protein BEH C4 column, $300 \AA, 1.7 \mu \mathrm{m}, 1 \times 100 \mathrm{~mm}$, Waters) and detected by mass spectroscopy (Xevo TQ-S, Waters) with sodium formate infusion into the ionization chamber. To detect changes in phosphoinositide levels after activation of muscarinic receptors, whole SCG were cut into small pieces and treated for $1 \mathrm{~min}$ with $10 \mu \mathrm{M}$ oxotremorine methiodide (Oxo-M) before the reaction was stopped by addition of ice-cold methanol/1 N HCl. Tsa201 cells transiently transfected with muscarinic receptors $\left(M_{1} R s\right)$ were equally treated with Oxo-M for $1 \mathrm{~min}$, followed by stoppage of the reaction ice-cold methanol/1 N HCl. Extraction of lipids was performed as described above. To normalize for cell numbers, 10\% of each sample was removed before lipid extraction and genomic DNA was extracted with GeneJet Genomic DNA Purification Kit (Thermo Scientific) according to the manufacturer's instructions. Genomic DNA amounts were quantified by spectrophotometry and used for normalization of lipid signal intensities.

FRET and calcium photometry. Optical measurements of calcium and Förster resonance energy transfer (FRET) were performed on single neurons by whole-cell photometry (not with images) as previously described (Falkenburger et al., 2010a,b, 2013; Dickson et al., 2013). Cells were illuminated by a grating-controlled monochromatic light source (Polychrome IV; TILL Photonics). For measurements of cytoplasmic-free $\mathrm{Ca}^{2+}$, neurons were loaded with $2 \mu \mathrm{M}$ fura-2-AM (Invitrogen) dissolved in Ringer's solution containing $0.02 \%$ pluronic acid F- 68 . Fura- 2 signals were reported as the fluorescence ratio with two wavelengths of excitation, F340/F380. FRET was measured as the ratio of corrected fluorescence from YFP and CFP after excitation of CFP molecules and is reported as $\mathrm{F}_{\mathrm{YFP}} / \mathrm{F}_{\mathrm{CFP}}$ (FRETr).

Western blot analysis. Cytoplasmic proteins from SCG neurons and tsA201 cells were isolated and purified with the Mem-PER Plus Membrane Protein Extraction Kit (Pierce Protein Biology Products, Thermo Scientific) according to the manufacturer's instructions. Membrane proteins were extracted as follows: cells were spun down at $300 \times g$ and resuspended in $1 \mathrm{ml} \mathrm{H}_{2} \mathrm{O}$. Cell suspensions were frozen in liquid nitrogen and thawed at $37^{\circ} \mathrm{C}$ in a water bath. This step was repeated twice before samples were centrifuged for $3 \mathrm{~min}$ at $300 \times g$ at $4^{\circ} \mathrm{C}$. The supernatant was removed and spun again at $20,000 \times g$ for $20 \mathrm{~min}$ at $4^{\circ} \mathrm{C}$. The pellet was resuspended in HEPES-lysis buffer (150 mm NaCl, $10 \mathrm{~mm}$ HEPES, $0.5 \%$ Triton X-100, pH 7.4). Protein concentration was determined by BCA protein assay (Pierce Protein Biology Products, Thermo Scientific). Twenty micrograms of protein was separated by SDS-PAGE using standard techniques. The primary antibody against rat and human PLC $\beta 1$ 
Table 1. Rate constants and parameters for SCG neuron and tsA201 cell models

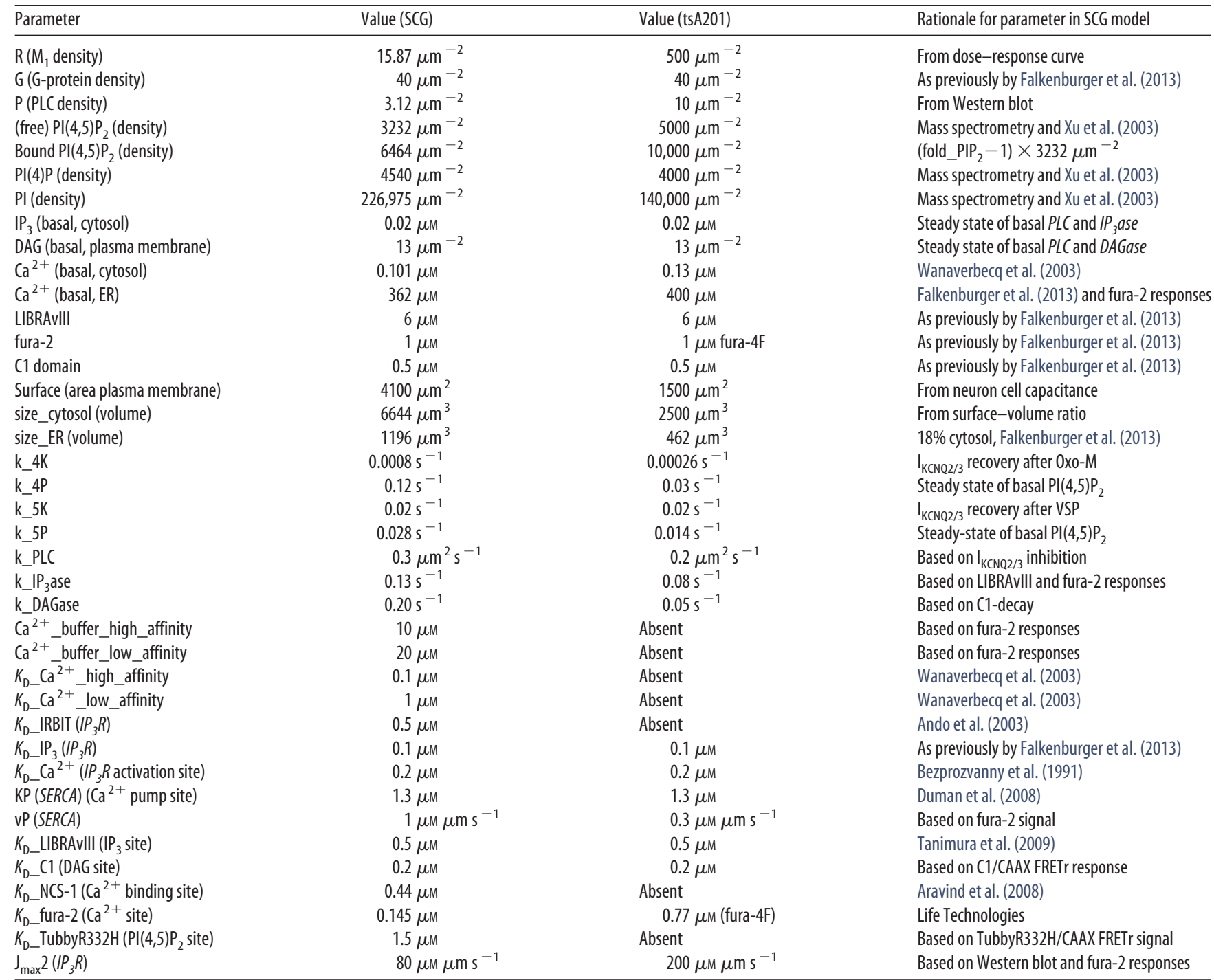

was used at a concentration of $1 \mu \mathrm{g} / \mathrm{ml}$ (Abcam, ab140746); anti-IP ${ }_{3} \mathrm{R} 1$ and anti-IP ${ }_{3} \mathrm{R} 2$ were used at a dilution of 1:500 (Alomone Labs, ACC-019 and ACC-116), anti-IRBIT (Abcam, ab178693) was used at a dilution of 1:10,000, and all were detected using a horseradish peroxidase-coupled secondary antibody (1:5000, Santa Cruz Biotechnology) and chemiluminescence (Pierce ECL Western Blotting Substrate, Pierce Protein Biology Products, Thermo Scientific). Recombinant protein of human phospholipase $C \beta 1$ (PLC $\beta 1$ ) was used for Western blot analysis (OriGene Technologies).

Mathematical modeling. The Virtual Cell software environment (University of Connecticut Health Center, http://www.nrcam.uchc.edu) was used to develop a kinetic description of phosphoinositide metabolism in neurons. As a starting point and for comparison, we used a compartmental model (Dickson et al., 2013; Falkenburger et al., 2013) that had been developed to describe observations on the tsA201 cell line. Conditions that were changed to resemble the results obtained in SCG neurons are shown in Figures $3 A, B$, $5 E, 8 C, G$, and Table 1 . Model rate constants were chosen manually to fit experimental data. To compare modeled calculations to data obtained from FRET and electrophysiological recordings, we segmented the traces into onset and recovery of the effect and normalized to basal levels in each case to correct for incomplete recovery. The modified Virtual Cell Model "hillelab: KruseVivasTraynorKaplanHille_PI-metabolism_SCG_2015" is publicly available at http://www.vcell.org/.

Data analysis. We used IGOR Pro (IGOR Software, RRID:nlx_156887, WaveMetrics) and Excel (Microsoft) to analyze data. Statistics are given as mean \pm SEM. Student's $t$ test was used to test for statistical significance. $p$ values $<0.05$ were considered significant.

\section{Results}

We start by explaining the logic of the experiments. We first make empirical measurements of lipid metabolism and then bring in kinetic reasoning to develop a clearer understanding of several differences in the underlying steps in neurons. The lipids are followed by electrophysiological and optical indicators and by chemical analysis. Figure $1 A$ shows the steps to be analyzed. They include the lipid 4- and 5-kinases (enzymes are shown in red) that phosphorylate $\mathrm{PI}$ to $\mathrm{PI}(4) \mathrm{P}$ and $\mathrm{PI}(4,5) \mathrm{P}_{2}$, the lipid 4 - and 5 -phosphatases that reverse these reactions, and the PLC that hydrolyzes $\mathrm{PI}(4,5) \mathrm{P}_{2}$ into DAG and $\mathrm{IP}_{3}$. We perturb lipid levels by activating enzymes. Thus, when PLC is activated by receptors, the pools of $\mathrm{PI}(4) \mathrm{P}$ and $\mathrm{PI}(4,5) \mathrm{P}_{2}$ both become depleted (see the next section) and recovery of $\mathrm{PI}(4,5) \mathrm{P}_{2}$ is a two-step reaction that requires both the 4 - and the 5-kinase. When we want to analyze the kinetics of the 5-kinase alone, we use a special voltage-sensing lipid phosphatase (VSP; Murata and Okamura, 2007) that dephosphorylates $\mathrm{PI}(4,5) \mathrm{P}_{2}$ to $\mathrm{PI}(4) \mathrm{P}$ (Fig. $\left.1 A\right)$. Subsequent recovery of $\mathrm{PI}(4,5) \mathrm{P}_{2}$ then requires only the 5-kinase. 
A

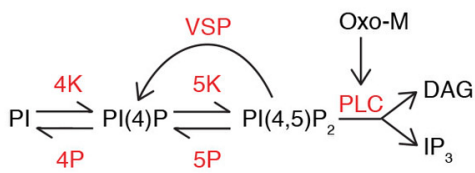

C

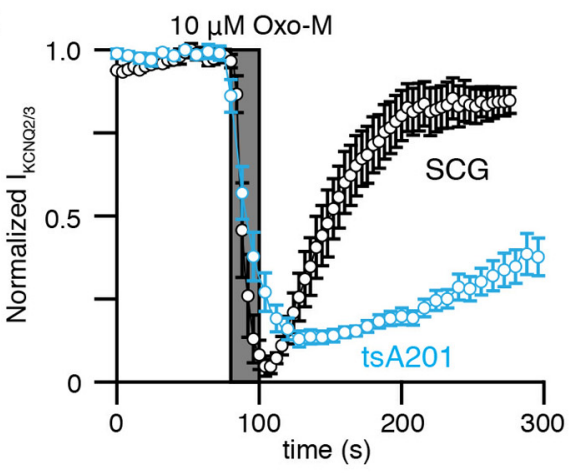

F

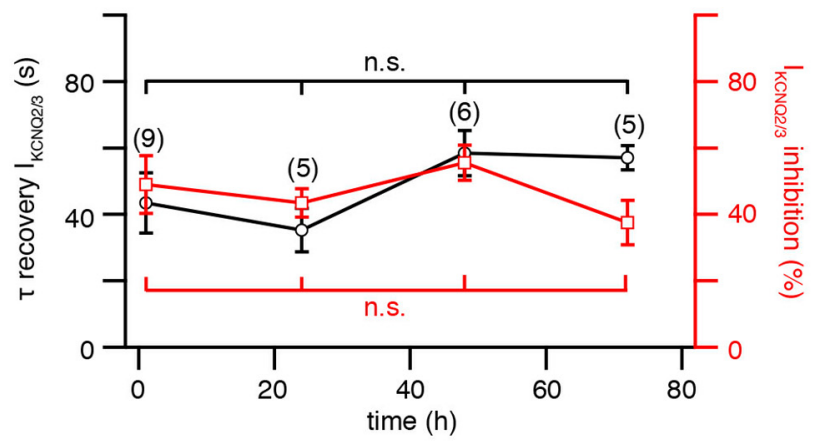

I
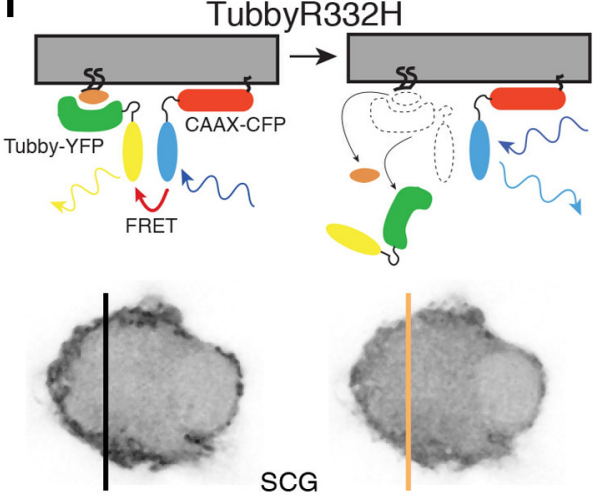

L Before

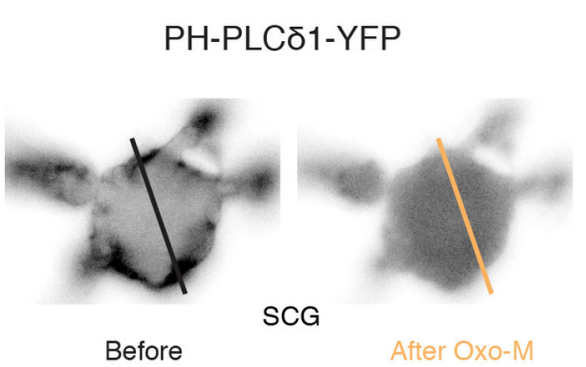

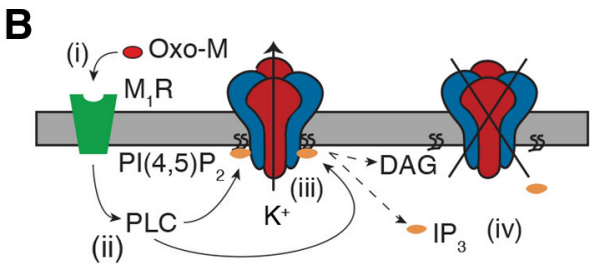

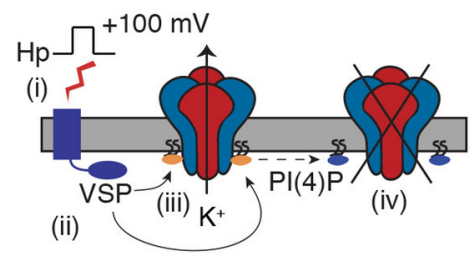

D
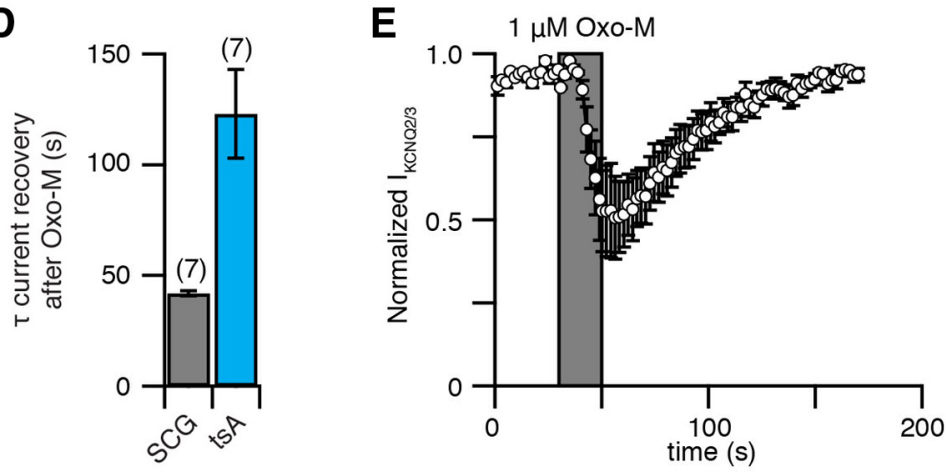

G

H
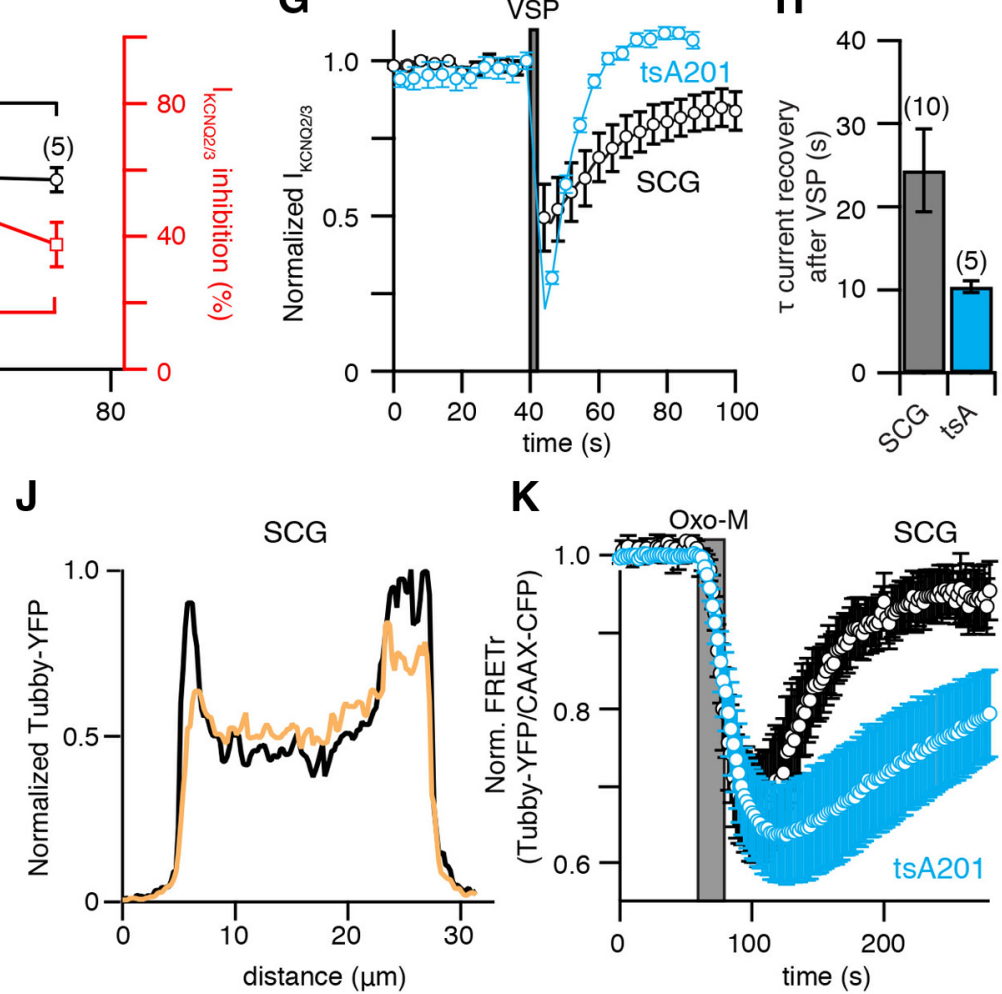

K

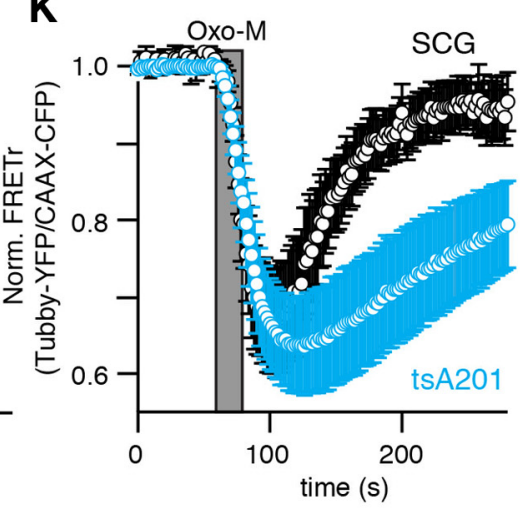

M

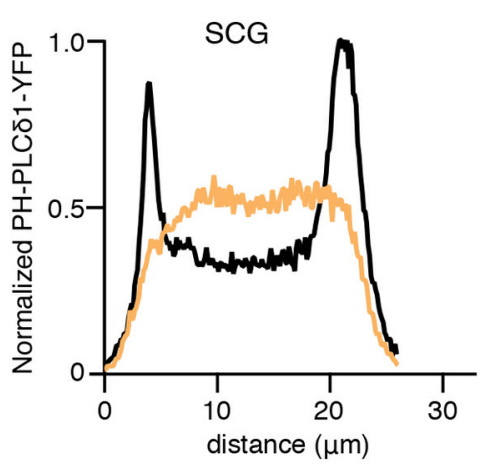

$\mathbf{N}$

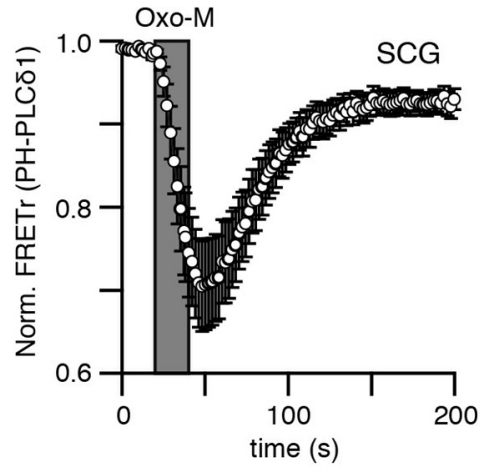


Fast recovery of $\mathrm{I}_{\mathrm{KCNQ} 2 / 3}$ and $\mathrm{PI}(4,5) \mathrm{P}_{2}$ in SCG neurons

In the first experiments, we monitored the levels of $\mathrm{PI}(4,5) \mathrm{P}_{2}$ in the plasma membrane of SCG neurons using the endogenous $\mathrm{PI}(4,5) \mathrm{P}_{2}$-dependent voltage-gated potassium channel KCNQ2/3 $\left(\mathrm{K}_{\mathrm{V}} 7.2 / 7.3\right)$ as a reporter (Suh and Hille, 2002; Zhang et al., 2003; Winks et al., 2005). These channels underlie the M-current in SCG neurons (Brown and Passmore, 2009). We depleted $\mathrm{PI}(4,5) \mathrm{P}_{2}$ by activation of $\mathrm{M}_{1}$ Rs through a $20 \mathrm{~s}$ application of a muscarinic agonist, $10 \mu \mathrm{M}$ Oxo-M (Fig. $1 B$, left). During agonist application, $\mathrm{I}_{\mathrm{KCNQ} 2 / 3}$ declined rapidly and almost completely, and upon removal of agonist, current recovered with a time constant of $42 \pm 1 \mathrm{~s}$ at room temperature (Fig. $1 C$ ). Closure of these channels makes the neurons much more excitable (Brown et al., 2007), and their reopening terminates the period of raised excitability. The experiment was repeated for comparison in tsA201 cells transfected with KCNQ2, KCNQ3, and $M_{1} R$. Now the current recovered with a much longer time constant of $123 \pm 20 \mathrm{~s}$ upon removal of the agonist (Fig. $1 C, D$; Jensen et al., 2009). Thus, $\mathrm{PI}(4,5) \mathrm{P}_{2}$ pools are replenished more rapidly in the neurons than in tsA201 cells.

The experiments shown in Figure 1, $C$ and $D$, were conducted with neurons cultured for $48 \mathrm{~h}$ after isolation. To test whether the culture conditions alter the time constant of M-current recovery, we repeated the experiments at different culture times, ranging from 1 to $72 \mathrm{~h}$ after isolation. In addition, we used only $1 \mu \mathrm{M}$ Oxo-M, which had previously been shown to cause half-maximal inhibition of M-current (Winks et al., 2005) and allowed us to observe potential alterations in $\mathrm{M}_{1}$ receptor signaling better. In freshly dissociated neurons, cultured only for $1 \mathrm{~h}$, the application of $1 \mu \mathrm{M}$ Oxo-M inhibited $\sim 50 \%$ of $\mathrm{M}$-current and the time con-

\footnotetext{
Figure 1. Faster kinetics of $\mathrm{I}_{\mathrm{KCNQ} 2 / 3}$ and $\mathrm{PI}(4,5) \mathrm{P}_{2}$ recovery in $\mathrm{SCG}$ neurons versus ts $\mathrm{A} 201$ cells. $\boldsymbol{A}$, Overview of the analyzed reactions of PI metabolism. Red, Enzymes. $\boldsymbol{B}$, Schematic of closure of KCNQ2/3 channels due to $\mathrm{PI}(4,5) \mathrm{P}_{2}$ hydrolysis. Left, Activation of phospholipase $C$ after binding of the ligand $0 \times 0-M$ to $M_{1} R$. Right, Activation of a VSP by membrane depolarization. C, Normalized KCNQ2/3 tail current amplitude upon activation of $\mathrm{M}_{1}$ receptors by $10 \mu \mathrm{M}$ 0xo-M measured with whole-cell recordings from SCG neurons and tsA201 cells. D, Time constants of tail current amplitude recovery after removal of $0 \times 0-M$. Numbers in brackets indicate number of experiments. $\boldsymbol{E}$, Normalized KCNQ2/3 tail current amplitude upon activation of $\mathrm{M}_{1}$ receptors by $1 \mu \mathrm{m}$ 0xo-M measured with whole-cell recordings from SCG neurons $1 \mathrm{~h}$ after isolation. $\boldsymbol{F}$, Time constants of tail current amplitude recovery after activation of $\mathrm{M}_{1} \mathrm{Rs}$ with $1 \mu \mathrm{M}$ $0 \times 0-M$ at different time points after isolation of $S C G$ neurons (black) or percentage inhibition of M-current (red). G, Same as in C but with activation of VSP. H, Time constants of tail current amplitude recovery after VSP activation. $I$, SCG neurons were transfected by intranuclear injection with plasmids encoding TubbyR332H-YFP and CAAX-CFP to measure changes in plasma membrane $\mathrm{PI}(4,5) \mathrm{P}_{2}$ levels with ratiometric FRETr recordings. Top, Schematic of FRETr measurements before and after depletion of $\mathrm{PI}(4,5) \mathrm{P}_{2}$. Bottom, Negative contrast confocal image of fluorescence intensity distribution of TubbyR332 $\mathrm{H}$ before (left) and after (right) application of Oxo-M.J, Line scans of TubbyR332H distribution before (black) and after (orange) application of Oxo-M along the lines indicated in $\boldsymbol{I}$. $\boldsymbol{K}$, Normalized FRETr between TubbyR332H-YFP and CAAXCFP upon application of 0xo-M to SCG neurons and tsA201 cells. L, Negative contrast confocal images of PH-PLC $\delta 1-Y F P$ fluorescence in a SCG neuron before and $20 \mathrm{~s}$ after stimulation with $10 \mu \mathrm{M}$ 0xo-M. $\boldsymbol{M}$, Line scans showing fluorescence intensity distribution of PH-PLC $\delta 1-Y F P$ along lines indicated in $\boldsymbol{L}$ before (black) and after (orange) application of $0 \times 0-M$. $\boldsymbol{N}$, Mean normalized FRETr from SCG neurons transfected with PH-PLC $\delta 1$-CFP and -YFP upon stimulation of cells with Oxo-M.
}

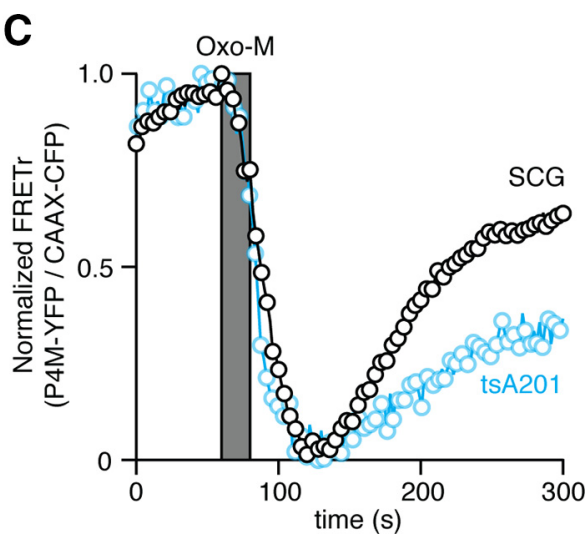
00 neurons for up to $72 \mathrm{~h}$ did not change the fraction of current inhibition or the time constant of M-current recovery (Fig. $1 F$ ), showing that the chosen culture conditions do not alter $\mathrm{M}_{1} \mathrm{R}$ signaling or the time constant of M-current recovery. Similar to recordings obtained from neurons cultured for $48 \mathrm{~h}$ and treated with $10 \mu \mathrm{M}$ Oxo-M, the time constant of current recovery was significantly faster than in tsA201 cells, suggesting that fast replenishment of $\mathrm{PI}(4,5) \mathrm{P}_{2}$ pools is an intrinsic property of sympathetic neurons.

Are both lipid kinases in Figure $1 \mathrm{~A}$ faster in neurons? To isolate the contribution of endogenous lipid 5-kinases, we expressed the VSP in SCG neurons. During a depolarizing voltage step to $+100 \mathrm{mV}$, VSP dephosphorylates $\mathrm{PI}(4,5) \mathrm{P}_{2}$ to $\mathrm{PI}(4) \mathrm{P}$, transiently depleting $\mathrm{PI}(4,5) \mathrm{P}_{2}$, and $\mathrm{KCNQ} 2 / 3$ channel activity decreases sharply (Fig. 1B, right). After the brief activation of VSP, $\mathrm{I}_{\mathrm{KCNQ} 2 / 3}$ was strongly suppressed and then recovered with a time constant of $24 \pm 5 \mathrm{~s}$ in SCG neurons and $10 \pm 1 \mathrm{~s}$ in tsA201 cells (Fig. $1 G, H$; Falkenburger et al., 2010b). Apparently, the endogenous 5 -kinase activity is lower in the neurons than in the tsA201 cells. Hence, we must hypothesize that the relative activity of the 4-kinase is markedly boosted in the neurons because the overall recovery of $\mathrm{I}_{\mathrm{KCNQ} 2 / 3}$ after PLC-activation is several-fold faster than in tsA201 cells. We test this notion in the next section.

To confirm the kinetic measurements of $\mathrm{PI}(4,5) \mathrm{P}_{2}$, we repeated the experiments with two other indicators of $\mathrm{PI}(4,5) \mathrm{P}_{2}$. The first was a YFP-tagged $\mathrm{PI}(4,5) \mathrm{P}_{2}$ binding domain from Tubby (TubbyR332H-YFP; Hughes et al., 2007). To monitor plasma-membrane Tubby by a FRET assay (Fig. 1I), we coexpressed TubbyR332H-YFP (FRET acceptor) with a small plasma membrane localized CFP-tagged protein (CAAX-CFP, FRET donor). Under basal conditions, fluorescence of TubbyR332H-YFP was localized to the plasma membrane of SCG neurons (Fig. $1 I, J$ ) and the FRET ratio (FRETr $\mathrm{F}_{\mathrm{YFP}} / \mathrm{F}_{\mathrm{CFP}}$ ) was high. Then activation of $\mathrm{M}_{1} \mathrm{R}$ led to a translocation of the domain to the cytoplasm and a drop of FRETr (Fig. $1 K$ ), indicating $\mathrm{PI}(4,5) \mathrm{P}_{2}$ hydrolysis. FRETr recovery during the washout had a time constant of $53 \pm 15 \mathrm{~s}$ in SCG neurons and a time constant of $127 \pm$ $25 \mathrm{~s}$ in tsA201 cells, corresponding well with our findings for $\mathrm{I}_{\mathrm{KCNQ} 2 / 3}$ recovery after receptor activation that overall $\mathrm{PI}(4,5) \mathrm{P}_{2}$ synthesis occurs more slowly in tsA201 cells.

As a second FRETr-based assay for $\mathrm{PI}(4,5) \mathrm{P}_{2}$, we repeated the experiments with CFP- and YFP-tagged versions of pleckstrin 
A
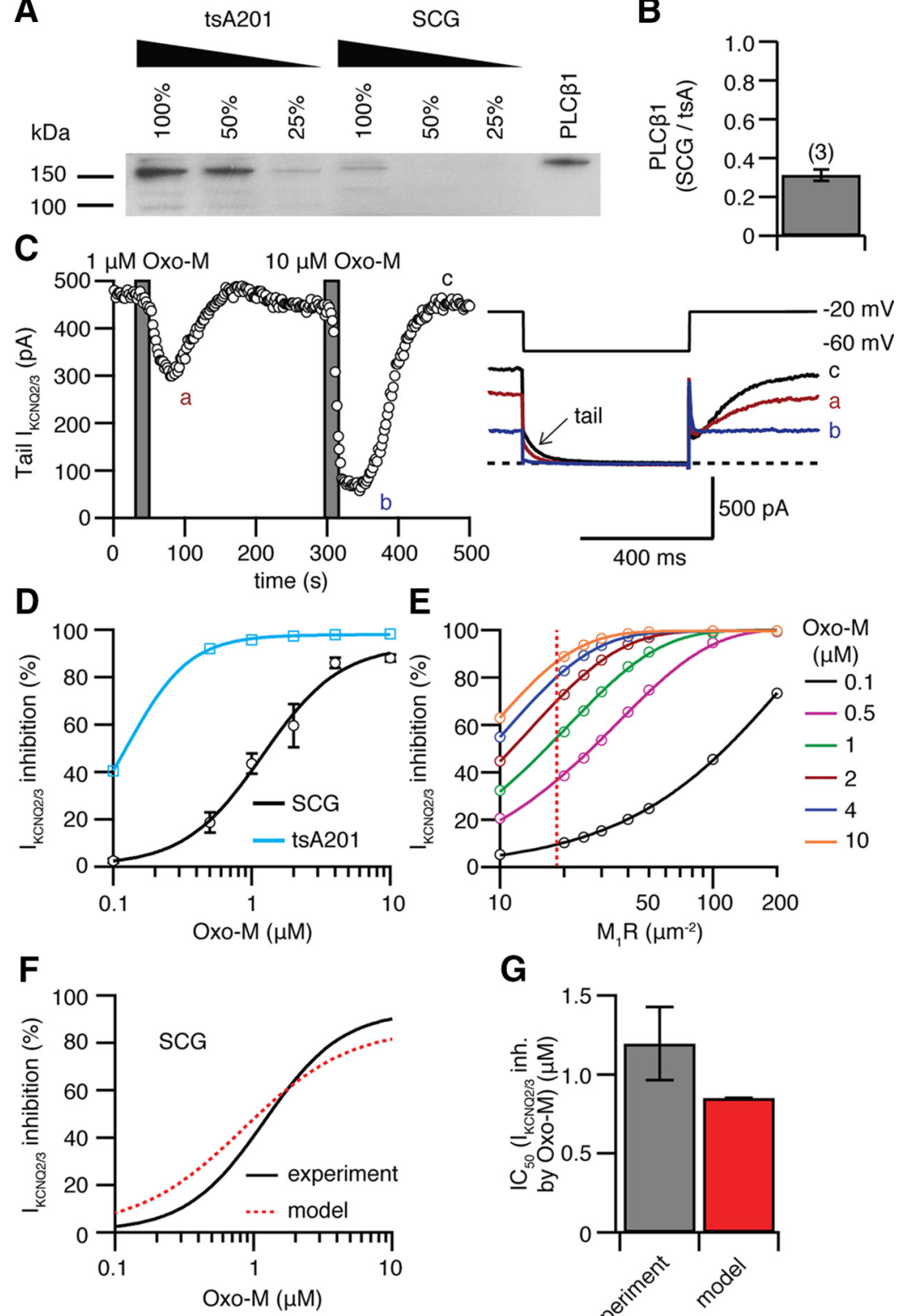

E

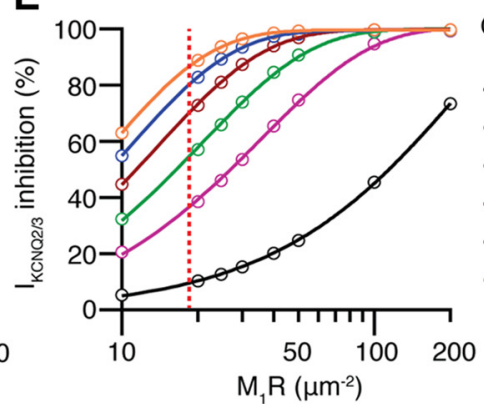

G

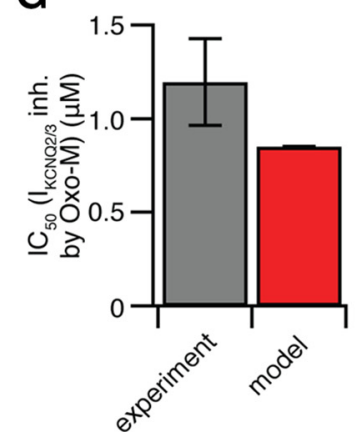

Figure 3. Estimation of PLC and M R Rexpression levels in SCG neurons. A, Western blot of cytoplasmic lysates of tsA201 cells and SCG neurons with an anti-PLC $\beta 1$ antibody. Protein amounts of the two lysates were normalized for equal amounts; percentages indicate dilution steps. "PLC $\beta 1$ " indicates detection of a recombinant $\operatorname{PLC} \beta 1$ protein used as a positive control for the primary antibody. $\boldsymbol{B}$, Percentage of PLC $\beta 1$ in SCG neurons compared with tsA201 cells as measured by analysis in $\boldsymbol{A}$. Number in brackets indicates number of experiments. $C$, Left, Time course of KCNQ2/3 tail current amplitude recorded from a SCG neuron upon application of indicated concentrations of $0 \mathrm{xo}-\mathrm{M}$. Right, Current traces corresponding to time points indicated by letters on the left. Arrow indicates tail currents. $\boldsymbol{D}, \mathrm{I}_{\mathrm{KCNQ} 2 / 3}$ inhibition evoked by $20 \mathrm{~s}$ applications of different concentrations of $0 \mathrm{xO}-\mathrm{M}$ in $\mathrm{SCG}$ neurons (black) or tsA201 cells (blue). $\boldsymbol{E}$, Modeled $I_{\text {KCN02/3 }}$ inhibition evoked by $20 \mathrm{~s}$ applications of different concentrations of $0 \times 0-M$ for indicated densities of $M_{1} R$. Dotted line indicates $M_{1} R$ density of 16 molecules $\mu m^{-2}$. $F$, Comparison of experimental (black) and modeled (red) dose-response curves for $\mathrm{K}_{\mathrm{KCN} 02 / 3}$ inhibition by 0xo-M in SCG neurons. G, $\mathrm{I}_{50}$ values for $\mathrm{K}_{\mathrm{KCN} 02 / 3}$ inhibition by 0x0-M in SCG neurons as measured experimentally $(n=5-25)$ and from our model.

homology $(\mathrm{PH})$ domains from PLC $\delta 1$. These experiments were done only in neurons. Similar to TubbyR332H, the PH-PLC $\delta 1$ domain probes were localized at the plasma membrane under basal conditions and FRETr was high, and the probes moved to the cytoplasm upon application of Oxo-M (Fig. $1 L, M)$. The time constant of PH domain FRETr recovery was $47 \pm 8 \mathrm{~s}$ (Fig. $1 N$ ), similar to the $53 \mathrm{~s}$ recovery of TubbyR332H FRETr and the $42 \mathrm{~s}$ recovery of $\mathrm{I}_{\mathrm{KCNQ} 2 / 3}$. Hence, the FRETr recordings with TubbyR332H and PH-PLC81 confirm that $\mathrm{I}_{\mathrm{KCNQ} 2 / 3}$ recovery tracks $\mathrm{PI}(4,5) \mathrm{P}_{2}$ recovery in SCG neurons and that overall $\mathrm{PI}(4,5) \mathrm{P}_{2}$ resynthesis is appreciably faster in SCG neurons than in tsA201 cells.

\section{Accelerated synthesis of PI(4)P in SCG neurons}

Our analysis of $\mathrm{I}_{\mathrm{KCNQ} 2 / 3}$ recovery after VSP stimulation implied that there is a faster lipid 4-kinase activity in SCG neurons. We used a recently developed fluorescent probe for PI(4)P (P4M; Hammond et al., 2014) to measure the kinetics of PI(4)P changes. In SCG neurons, a GFP-labeled version of $\mathrm{P} 4 \mathrm{M}$ showed a significant component at the plasma membrane under basal conditions, which, as expected, became mainly cytoplasmic after application of Oxo-M to SCG neurons (Fig. 2A,B). In basal conditions, there also was intracellular labeling, likely at the Golgi. To measure the time course at the plasma membrane, we cotransfected SCG neurons with a YFP-tagged P4M-probe and the plasma-membrane localized CAAXCFP. Under basal conditions there was FRETr between the two fluorophores as PI(4)P was present at the plasma membrane. Upon muscarinic stimulation, the FRETr decreased; P4M-probes were leaving the plasma membrane. Upon washout of the agonist, there was partial recovery with a time constant of $73 \pm 15 \mathrm{~s}$, reflecting resynthesis of PI(4)P (Fig. 2C). Similar experiments in tsA201 cells gave similar results except that the recovery of FRETr was threefold slower (Fig. 2C). With this direct measure we confirm that neurons synthesize PI(4)P faster than tsA201 cells.

\section{Determination of PLC and $M_{1} R$ expression levels in SCG neurons}

We now develop a more quantitative description of the underlying events. To deconvolve the rates of enzymatic steps, we adapted our earlier kinetic model of phosphoinositide metabolism in tsA201 cells (Dickson et al., 2013; Falkenburger et al., 2013) to our observations in SCG neurons. An important initial step was to determine the relative amounts of PLC and $M_{1} R$ proteins in SCG compared with tsA201 cells. We isolated cytoplasmic proteins from both cell types and detected PLC $\beta 1$ in these lysates by Western blot analysis with an anti-PLC $\beta 1$ antibody. Comparison of PLC $\beta 1$ signal intensities showed lower expression in superior cervical ganglia than in tsA201 cells when referred to a total protein basis (Fig. $3 A, B$ ). Accordingly we set the level of PLC $\beta 1$ in the model for SCG neurons to $\sim 31 \%$ of the level used in the tsA201 cell model (Fig. 3B; Table 1).

The surface density of receptors was very high in our $\mathrm{M}_{1} \mathrm{R}$ transiently transfected tsA201 cell model, 500 receptors $\mu \mathrm{m}^{-2}$ (Falkenburger et al., 2010a). As $\mathrm{M}_{1} \mathrm{R}$ is endogenously expressed 
A

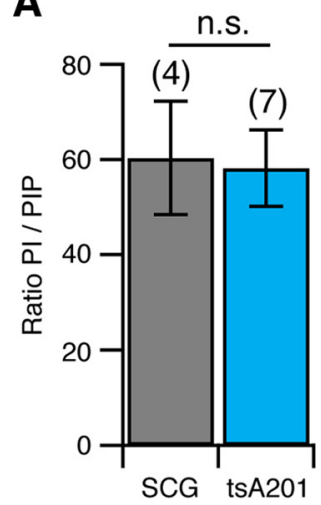

B

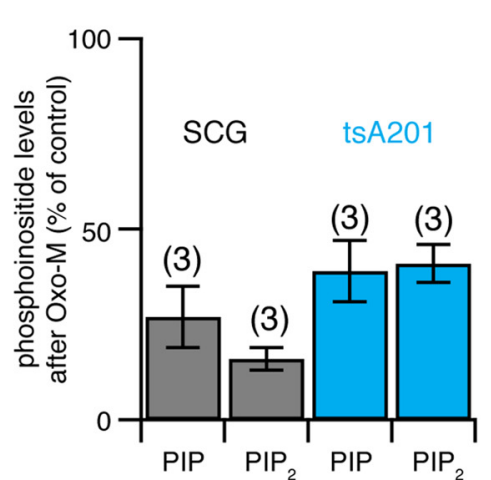

C

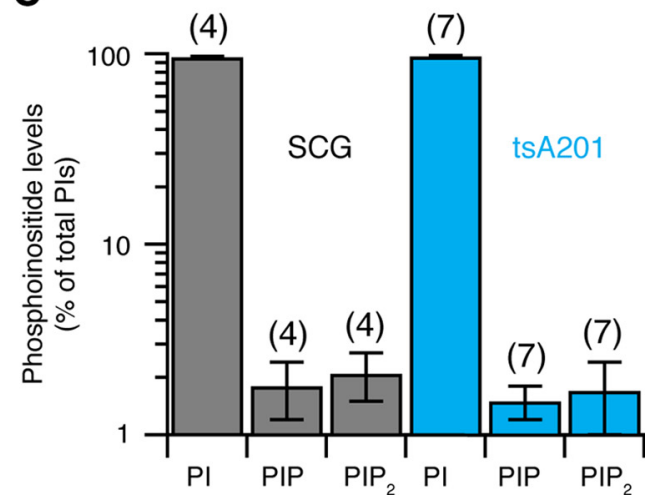

Figure 4. Phosphoinositide levels determined by mass spectrometry. $\boldsymbol{A}$, Ratio of total PI to total PIP as measured from SCG and tsA201 cells. $\boldsymbol{B}$, Levels of PIP and PIP 2 relative to controls from SCG and tsA201 cells after 1 min application of $10 \mu \mathrm{m}$ 0x0-M. C, Relative amounts of total PI, PIP, and PIP 2 as percentages of total phosphoinositides for SCG and tsA201 cells. Number in brackets indicates number of experiments.

in SCG neurons, we anticipated that the surface density might be significantly lower there. Our method of estimation combined electrophysiological recordings and mathematical modeling, following the concept that the functional surface density of $M_{1} R$ defines the concentration-response curve of $\mathrm{I}_{\mathrm{KCNQ} 2 / 3}$ to graded concentrations of Oxo-M. We measured $\mathrm{I}_{\mathrm{KCNO} 2 / 3}$ inhibition with $20 \mathrm{~s}$ applications of different concentrations of Oxo-M (Fig. 3C), finding an $\mathrm{IC}_{50}$ for $\mathrm{I}_{\mathrm{KCNQ} / 3}$ inhibition of $1.2 \pm 0.2 \mu \mathrm{M}$ Oxo-M (Fig. $3 D$ ), one order of magnitude higher than that needed in receptor-transfected tsA201 cells under similar conditions $(0.1$ $\mu \mathrm{M}$; Fig. 3D, data from Jensen et al., 2009). Our $\mathrm{IC}_{50}$ value for $\mathrm{I}_{\mathrm{M}}$ in SCG neurons is approximately twofold higher than a previously measured value of $0.7 \pm 0.1 \mu \mathrm{M}$ (Winks et al., 2005), a difference that is explained by the duration of Oxo-M application. We used only $20 \mathrm{~s}$ to permit for comparison to our previously measured $\mathrm{IC}_{50}$ in tsA201 cells, but not long enough for channel inhibition to reach a steady state at lower concentrations of Oxo-M. Winks et al. (2005) applied Oxo-M for $>1 \mathrm{~min}$, thereby measuring stronger $\mathrm{I}_{\mathrm{KCNQ} 2 / 3}$ inhibition at the lowest concentrations of Oxo-M.

We next used modeling to estimate the surface density of $M_{1}$ receptors. We simulated the Oxo-M concentration-response curves for varying $\mathrm{M}_{1} \mathrm{R}$ surface densities (Fig. $3 E$ ) and estimated a mean $M_{1} R$ surface density of $16 \pm 2$ receptors $\mu \mathrm{m}^{-2}$ as the best fit to the experiments (Fig. $3 F$ ). This density predicts an $\mathrm{IC}_{50}$ for $\mathrm{I}_{\mathrm{KCNQ} 2 / 3}$ of $0.9 \mu \mathrm{M}$ Oxo-M compared with the measured value of $1.2 \pm 0.2 \mu \mathrm{M}$ (Fig. $3 G$ ). It was used for all following simulations.

\section{Determination of phosphoinositide levels by mass spectrometry}

We had found a faster synthesis of PI(4)P from PI in SCG neurons. Such a speed up relative to tsA201 cells might be explained in two ways: (1) by an increased amount of PI relative to PI(4)P in neurons, or (2) by an increased specific activity of the lipid 4-kinase (Fig. 1A). We evaluated the first possibility by measuring the phosphoinositides directly using mass spectrometry.

Extraction of lipids, followed by derivatization, allowed successful detection of phosphoinositides. Note that mass spectrometry does not distinguish the positions of phosphorylation so here we refer to PIP and PIP $_{2}$ without being able to distinguish regioisomers. We found a ratio of PI/PIP of $60 \pm 12(n=4)$ for SCG neurons, and of $58 \pm 8(n=7)$ for tsA201 cells (Fig. $4 A)$. We confirmed that these lipids were accessible to hydrolysis by phospholipase $\mathrm{C}$ through activation of muscarinic receptors. Applica- tion of $10 \mu \mathrm{M}$ Oxo-M reduced PIP to $27 \pm 8 \%$ and $\mathrm{PIP}_{2}$ to $16 \pm$ $3 \%$ of control levels $(n=3$; Fig. $4 B)$. A similar reduction was observed in tsA201 cells transiently transfected with $M_{1}$ receptors. PIP was reduced to $39 \pm 8 \%$ and $\mathrm{PIP}_{2}$ to $41 \pm 5 \%(n=3$; Fig. $4 B$ ). It should be noted that we extracted total cellular lipids from all cell types within the SCG. Histologic analyses by several different groups have shown that neurons occupy the majority of the volume of the SCG (Jacobowitz and Woodward, 1968; Ichikawa et al., 2009; Ke et al., 2015), suggesting that the reduction of PIP and $\mathrm{PIP}_{2}$ detected by our measurements is mainly caused by activation of muscarinic receptors of neurons. In addition, we tested whether the relative abundance of different types of phosphoinositides of SCG neurons and tsA201 cells showed any significant differences. The three phosphoinositide classes PI, PIP, and PIP ${ }_{2}$ made up the following percentages of the total: $96.2 \pm 1.2 \%, 1.8 \pm 0.6 \%$, and $2.1 \pm 0.6 \%$ in neurons and $96.9 \pm 0.9 \%, 1.5 \pm 0.3 \%$, and $1.7 \pm 0.7 \%$ in tsA201 cells, respectively (Fig. 4C). These values are similar to previously reported ratios of phosphoinositides in other cell types (Willars et al., 1998; Xu et al., 2003) and show no significant differences between neurons and tsA201 cells. We conclude that neurons have the same overall relative abundance of PI, PIP, and $\mathrm{PIP}_{2}$ as other cells and the faster synthesis of $\mathrm{PI}(4) \mathrm{P}$ observed in neurons is not caused by a superabundance of PI.

\section{Modeling of phosphoinositide metabolism requires high activity of the lipid 4-kinase in SCG neurons}

Having determined levels of PLC $\beta 1$ and $\mathrm{M}_{1} \mathrm{R}$ for the model, and recognizing that the relative levels of $\mathrm{PI}, \mathrm{PIP}$, and $\mathrm{PIP}_{2}$ are not significantly different between neurons and tsA201 cells, we turned our attention to the rate constants of the lipid kinases and phosphatases, abbreviated $4 \mathrm{~K}, 4 \mathrm{P}, 5 \mathrm{~K}$, and $5 \mathrm{P}$ in Figure $1 \mathrm{~A}$. These rate constants were adjusted to approximate the measured time courses for $\mathrm{I}_{\mathrm{KCNQ} / 3}$ and the two FRET probes after $\mathrm{M}_{1} \mathrm{R}$ or VSP activation in neurons. The simulations then agreed reasonably with the experimental kinetics of inhibition and recovery of $\mathrm{I}_{\mathrm{KCNQ} / 3}$ (Fig. $5 A, B$, red lines) as well as with the loss of FRETr of Tubby-R332H and PH-PLC $\delta 1$ and recovery of FRETr (Fig. 5C,D, red line).

The major adjustments in the model were to increase the rate of phosphorylation from PI to PI(4)P by a factor of 4 and to decrease the rate of phosphorylation from $\mathrm{PI}(4) \mathrm{P}$ to $\mathrm{PI}(4,5) \mathrm{P}_{2}$ by a factor of 2 for neurons (Fig. $5 E$; Table 1 ). As in the experiments, the neuron model shows a strikingly faster synthesis of PI(4)P 
A

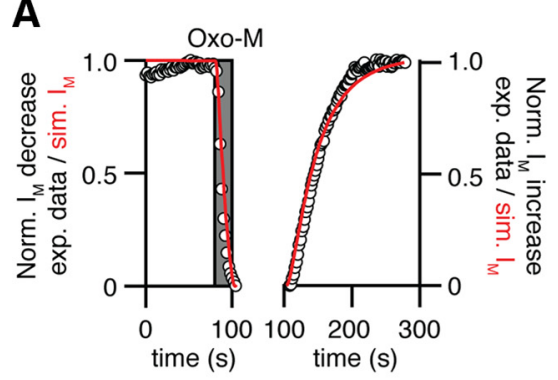

C
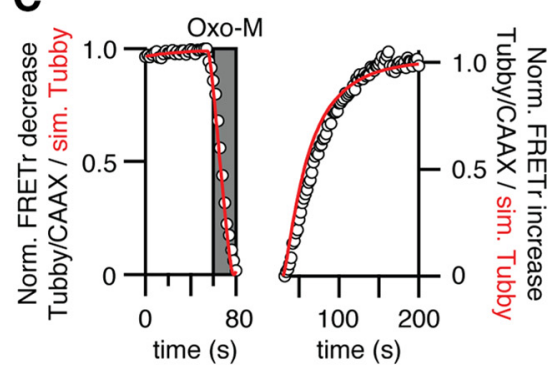

B

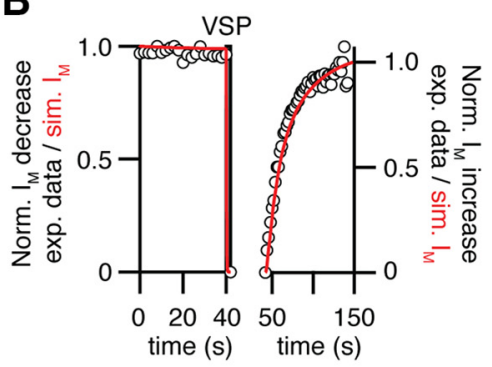

D
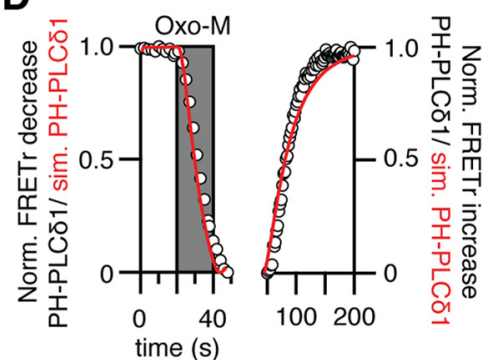

E

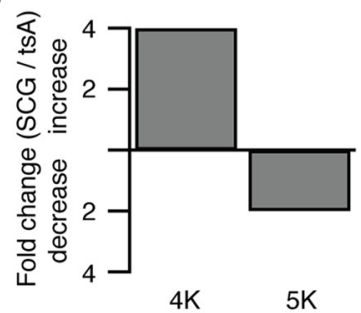

$\mathbf{F}$

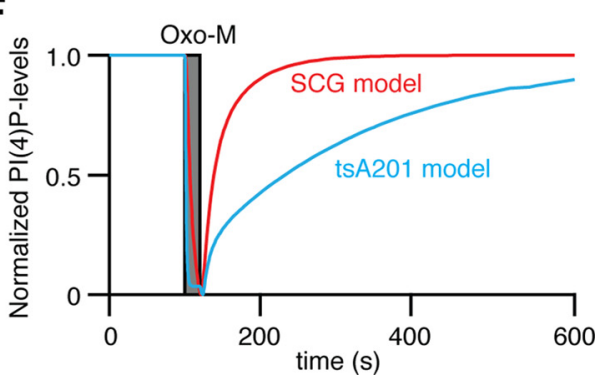

Figure 5. Modeling PI metabolism of SCG neurons requires faster lipid 4-kinase. $A$, Time course of normalized $\mathrm{I}_{\mathrm{KCNQ2} / 3}$ amplitude upon stimulation of SCG neurons with 0xo-M. Comparison of experimental data from whole-cell recordings (black) and normalized $I_{\text {KCNQ2/3 }}$ amplitude predicted by simulation (red). Traces were segmented into onset and recovery phases and normalized to basal levels to correct for partial recovery. $\boldsymbol{B}$, Same as in $\boldsymbol{A}$, but for activation of VSP. $\boldsymbol{C}$, Time course of normalized FRETr between TubbyR332H-YFP and CAAX-CFP upon stimulation of SCG neurons with 0xo-M as measured experimentally (black) and as predicted by simulation (red). Traces were segmented into onset and recovery phases and normalized to basal levels to correct for partial recovery. $\boldsymbol{D}$, Same as in $\boldsymbol{C}$, but for PH-PLC $\delta 1$ domains as FRETr reporters. The prediction plotted in red assumes no binding of PH-PLC $\delta 1$ domains to $\mathrm{IP}_{3}$. Note that the modeled traces approximate changes in FRETr as a cooperative square law of the membrane-bound fraction of PH-PLC $\delta 1$ domains as recently described (Itsuki et al., 2014). $\boldsymbol{E}$, Comparison of rate constant of synthesis of $\mathrm{PI}(4) \mathrm{P}$ and $\mathrm{PI}(4,5) \mathrm{P}_{2}$ between SCG neurons and tsA201 cells, expressed as fold-changes, SCG/tsA201. $F$, Simulated time courses of normalized levels of PI(4)P in SCG neurons (red, "neuron model") and tsA201 cells (blue, "tsA201 model") upon stimulation with $0 \times 0-M$.

(Fig. $5 F$ ), which leads to an overall faster recovery of $\mathrm{PI}(4,5) \mathrm{P}_{2}$ after transient depletion by PLC.

\section{DAG turnover is faster in SCG neurons, but $\mathrm{IP}_{3}$ turnover is not}

Next, we turned to the two second messengers generated by hydrolysis of $\mathrm{PI}(4,5) \mathrm{P}_{2}, \mathrm{DAG}$, and $\mathrm{IP}_{3}$. We measured their production and degradation in neurons transfected with fluorescent FRET-probes for $\mathrm{IP}_{3}$ (LIBRAvIII) and DAG (C1-YFP donor and membrane-bound CAAX-CFP acceptor; Fig. 6A). These probes indicated significant and rapid generation of $\mathrm{IP}_{3}$ and DAG during muscarinic stimulation (Fig. $6 B, E$ ) and a relatively fast decay with time constants of $73 \pm 9 \mathrm{~s}$ for $\mathrm{IP}_{3}$-bound LIBRAvIII and $15 \pm 5 \mathrm{~s}$ for DAG-bound C1-domains. We used these measured kinetics together with the affinities of the probes (Table 1), to adapt our model for SCG neurons. The chosen PLC, $M_{1} R$, and $\mathrm{PI}(4,5) \mathrm{P}_{2}$ levels (Table 1 ) turned out to be appropriate. We adjusted the rate constants of processes metabolizing DAG and $\mathrm{IP}_{3}$ to reproduce the observed kinetics (Fig. 6C, D, F, G; Table 1). The

modeled kinetics of $\mathrm{IP}_{3}$ production and degradation are almost identical for SCG neurons and tsA201 cells (Dickson et al., 2013), suggesting a similarity of the underlying machinery (see Fig. $7 A$ ). On the other hand, although DAG production follows a similar time course in these two cell types, its degradation is faster in SCG neurons (Fig. 7B). Hydrolysis of PI $(4,5) \mathrm{P}_{2}$ and closure of $\mathrm{PI}(4,5) \mathrm{P}_{2}$-dependent KCNQ2/3 channels also are kinetically indistinguishable between the two types of cells, suggesting that their endogenous PLCs have similar activity. Nevertheless, in the model, resynthesis of $\mathrm{PI}(4,5) \mathrm{P}_{2}$ happens significantly faster in SCG neurons than in tsA201 cells (Fig. 7C) as was observed, so simulated KCNQ2/3 channel activity recovers much more quickly (Fig. $7 D)$.

\section{Modeling suggests that regulation of $\mathrm{IP}_{3} \mathrm{R}$-availability and cytoplasmic $\mathrm{Ca}^{2+}$-buffering limit $\mathrm{Ca}^{2+}$ elevations from intracellular stores}

As Oxo-M initiates fast and sizeable IP production in SCG neurons with calculated peak concentrations of $\sim 3 \mu \mathrm{M}$ one might expect a significant release of $\mathrm{Ca}^{2+}$ from intracellular stores via $\mathrm{IP}_{3}$ receptors $\left(\mathrm{IP}_{3} \mathrm{R}\right)$. In tsA201 cells, $\sim 2 \mu \mathrm{M} \mathrm{IP} \mathrm{I}_{3}$ is sufficient to evoke almost maximal release of $\mathrm{Ca}^{2+}$ from stores, and peak $\mathrm{IP}_{3}$ concentrations of $\sim 13 \mu \mathrm{M}$ do not lead to significantly larger $\mathrm{Ca}^{2+}$ release. Accordingly, we loaded SCG neurons with fura-2-AM to measure changes in cytoplasmic $\mathrm{Ca}^{2+}$ levels ratiometrically. In unclamped cells, we wanted to avoid action potential firing that would open voltage-gated calcium channels. Therefore, we bathed the cells with $100 \mathrm{~nm}$ tetrodotoxin (TTX). As others have reported (Cruzblanca et al., 1998; del Río et al., 1999; Zaika et al., 2007), upon stimulation of these neurons with $10 \mu \mathrm{M}$ Oxo-M there was only a small $\mathrm{Ca}^{2+}$ rise, suggesting very little release of $\mathrm{Ca}^{2+}$ from intracellular stores (Fig. 8A). To check whether the $\mathrm{Ca}^{2+}$ increase is due to opening of low-threshold voltage-gated calcium channels, which could still occur with TTX, we repeated the

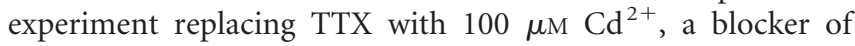
voltage-gated calcium channels. We still observed a small cytoplasmic fura-2 signal under these conditions (Fig. 8B). Hence, it must be mediated by $\mathrm{Ca}^{2+}$ release from intracellular stores, and we had to consider why it is so small compared with the large increase seen with the same Oxo-M stimulus in tsA201 cells (Dickson et al., 2013).

We tested alternative hypotheses with the model. First, we tested whether low $\mathrm{IP}_{3} \mathrm{R}$ levels can explain small $\mathrm{Ca}^{2+}$ signals. The assumed protein level of $\mathrm{IP}_{3} \mathrm{Rs}$ had to be lowered to only $0.005 \%$ of the previous value to match the observed $\mathrm{Ca}^{2+}$ signals (data not shown). However, Western blot analysis of neurons did not confirm such a reduction in $\mathrm{IP}_{3} \mathrm{R}$ protein levels (Fig. $8 C$ ). Instead, the protein amounts of $\mathrm{IP}_{3} \mathrm{R} 1$ and $\mathrm{IP}_{3} \mathrm{R} 2$ were reduced by 
only $60 \%$ in SCG neurons. Therefore, we considered other explanations.

It has been proposed that $M_{1}$ receptors in SCG neurons are too far away from the ER membrane to activate $\mathrm{IP}_{3}$ Rs (Delmas et al., 2002; Zaika et al., 2011; Zhang et al., 2013). This hypothesis requires a fast local degradation of released $\mathrm{IP}_{3}$. We developed a two-dimensional spatial model to ask how far $\mathrm{IP}_{3}$ might diffuse before it eventually is degraded. We started with the published diffusion coefficient for $\mathrm{IP}_{3}(283$ $\mu \mathrm{m}^{2} \mathrm{~s}^{-1}$; Allbritton et al., 1992), and the experimentally determined degradation rate of $\operatorname{IP}_{3}\left(0.13 \mathrm{~s}^{-1}\right.$, equivalent to a $7.7 \mathrm{~s}$ lifetime) in SCG neurons (Fig. 6B). Assuming that the $\mathrm{IP}_{3}$ degrading enzymes are uniformly distributed, this calculation showed that $\mathrm{IP}_{3}$ would diffuse beyond 50 $\mu \mathrm{m}$ before half of it is degraded (Fig. $8 D$ ). This distance is larger than the diameter of the soma of the neuron and several orders of magnitude larger than the expected distance between points of $\mathrm{IP}_{3}$-generation at the plasma membrane and the intracellular $\mathrm{Ca}^{2+}$ stores. Using a realistic geometry in a three-dimensional spatial model from an actual SCG neuron, the predicted profile of $\mathrm{IP}_{3}$ showed an almost uniform rise throughout the cytoplasm (Fig. 8E,F). A second three-dimensional spatial model in which we simulated muscarinic receptors on only one side of the cell did reveal an initial gradient of $\mathrm{IP}_{3}$ in the cytoplasm. However, within a couple of seconds $\mathrm{IP}_{3}$ again became uniform throughout the cytoplasm (Fig. 9A-C). We conclude from these simulations that under the observed rate of $\mathrm{IP}_{3}$ degradation, and no barriers impeding $\mathrm{IP}_{3}$ diffusion, $\mathrm{IP}_{3}$ should be able to bind to $\mathrm{IP}_{3} \mathrm{Rs}$ anywhere in the soma.

A third possibility is that $\mathrm{IP}_{3}$ Rs of SCG neurons, though present, are inhibited. IRBIT $\left(\mathrm{IP}_{3} \mathrm{R}\right.$-binding protein released with inositol 1,4,5-trisphosphate), an inhibitor that interacts with $\mathrm{IP}_{3} \mathrm{Rs}$ and is displaced competitively when $\mathrm{IP}_{3}$ binds, is expressed in the brain (Ando et al., 2003, 2006). We detected expression of IRBIT in superior cervical ganglia by Western blot (Fig. 8G), in agreement with previous reports showing expression of IRBIT by immunofluorescence (Zaika et al., 2011). When bound to an $\mathrm{IP}_{3} \mathrm{R}$, IRBIT renders the $\mathrm{IP}_{3}$ binding domain unavailable for $\mathrm{IP}_{3}$. Therefore, higher $\mathrm{IP}_{3}$ concentrations are required to displace IRBIT and activate receptors. In addition, it has been shown that the intracellular $\mathrm{Ca}^{2+}$-buffering of SCG neurons is due to two pools of $\mathrm{Ca}^{2+}$-buffers with equivalent $\mathrm{K}_{\mathrm{D}}$ values of $100 \mathrm{nM}$ and $1 \mu \mathrm{M}$ (Wanaverbecq et al., 2003). We tested by simulation whether competition by IRBIT or a similar molecule together with strong buffering of released $\mathrm{Ca}^{2+}$ could account for the small amplitude of the fura-2 signal observed upon muscarinic stimulation. Addition of a species with the properties of IRBIT and of two $\mathrm{Ca}^{2+}$ buffering pools into our model (Fig. $8 H$; Table 1) sufficed to reproduce the experimental data (Fig. $8 I, J$ ). They predict an increase in free cytoplasmic $\mathrm{Ca}^{2+}$ of only $20 \mathrm{~nm}$ upon activation of $\mathrm{M}_{1} \mathrm{R}$ by a supramaximal concentration of ligand.

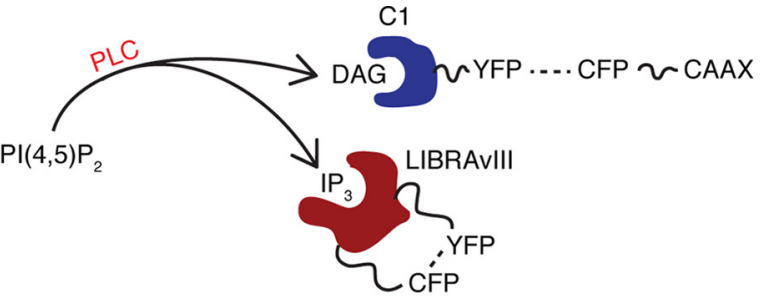

D
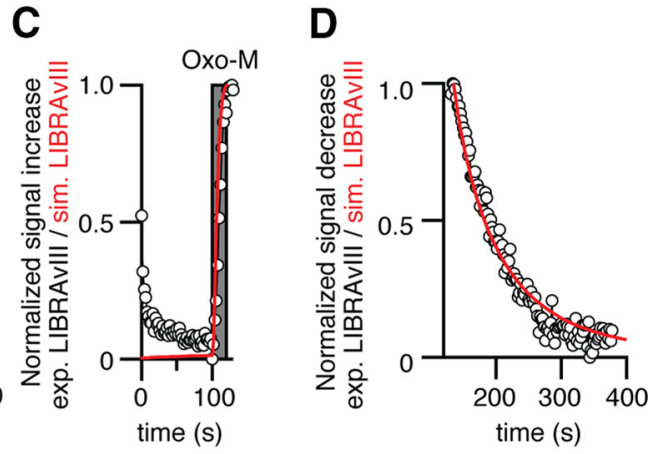

G
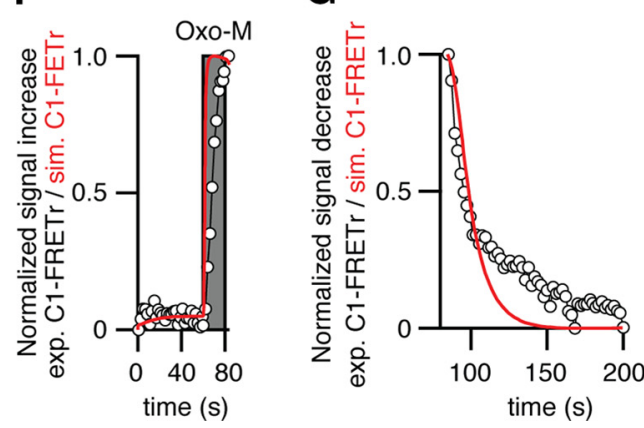

Figure 6. Kinetics of $\mathrm{IP}_{3}$ and $D A G$ signals after $\mathrm{M}_{1}$ R activation. $\boldsymbol{A}$, Schematic for detection of DAG and $I \mathrm{P}_{3}$ by FRET recordings. $\boldsymbol{B}$, Mean normalized FRETr of LIBRAvill in response to $10 \mu \mathrm{m}$ 0xo-M in SCG neurons (inverted scale, $\mathrm{F}_{C F P} / \mathrm{F}_{\mathrm{YFP}}$ ). C, D, Overlay of modeled LIBRAvlll response (red) on the time course of normalized inverted LIBRAvlll-FRETr evoked by stimulation of SCG neurons with recovery. $\boldsymbol{E}$, Same as in $\boldsymbol{B}$, but SCG neurons were transfected with C1-YFP and CAAX-CFP to measure changes in DAG levels $\left(\mathrm{F}_{\mathrm{YFP}} / \mathrm{F}_{\mathrm{CFP}}\right)$. Note different time scale. $\boldsymbol{F}, \mathbf{G}$, Same as in $\mathbf{C}, \boldsymbol{D}$, but for FRETr data and modeled C1-YFP/CAAX-CFP signal.

It has been shown that the $\mathrm{Ca}^{2+}$-binding protein neuronal calcium sensor-1 (NCS-1), which is highly expressed in SCG neurons, interacts with and stimulates lipid 4-kinases in its $\mathrm{Ca}^{2+}$ bound form (Zhao et al., 2001; Rajebhosale et al., 2003; Strahl et al., 2003; Gamper et al., 2004; Winks et al., 2005). We used our model to address the question whether the small rise in cytoplasmic $\mathrm{Ca}^{2+}$ upon muscarinic stimulation would be sufficient to convert NCS-1 into its $\mathrm{Ca}^{2+}$-bound form and stimulate lipid 4-kinases. We included a species with NCS-1's properties into our model and used the published $\mathrm{K}_{\mathrm{D}}$ of NCS-1 for free $\mathrm{Ca}^{2+}$ (Aravind et al., 2008). Our simulations show that stimulation with $10 \mu \mathrm{M}$ Oxo-M for $20 \mathrm{~s}$ increases the amount of $\mathrm{Ca}^{2+}$-bound NCS-1 by only $2 \%$ (Fig. $9 D, E$ ). Interestingly, omitting the restriction of $\mathrm{IP}_{3}$-binding to $\mathrm{IP}_{3} \mathrm{R}$ by removing the species with IRBIT's properties from the model leads to a strong increase of $\mathrm{Ca}^{2+}$-bound NCS-1 by $75 \%$ (Fig. $9 D, E$ ), illustrating the important role of a protein with IRBIT's properties for $\mathrm{Ca}^{2+}$ dependent processes in SCG neurons. In conclusion, our simulations argue against a strong activation of NCS-1 by $\mathrm{Ca}^{2+}$ release from intracellular stores upon muscarinic stimulation, although they have not ruled out some role of NCS-1 for the fast phosphoinositide metabolism in SCG neurons. 
A

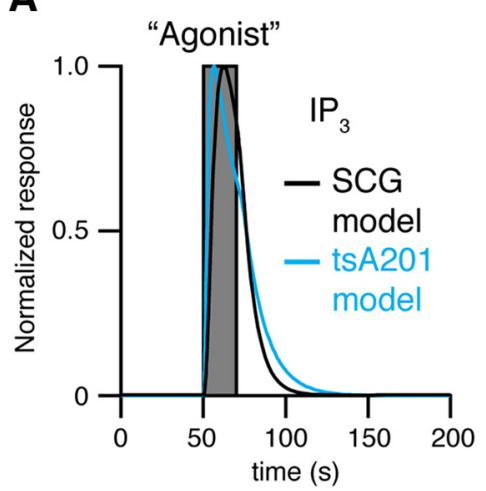

C

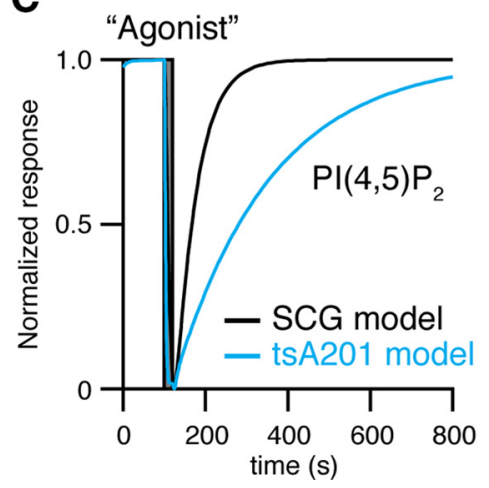

B

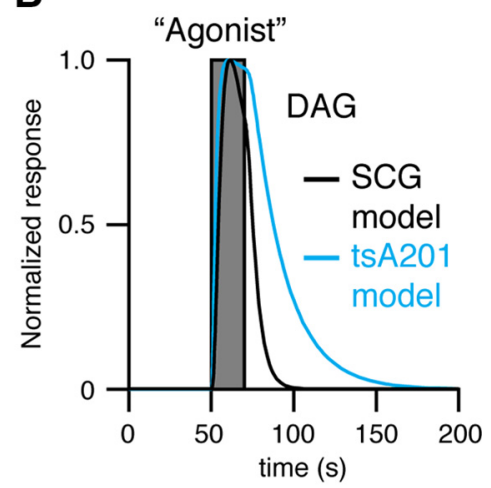

D

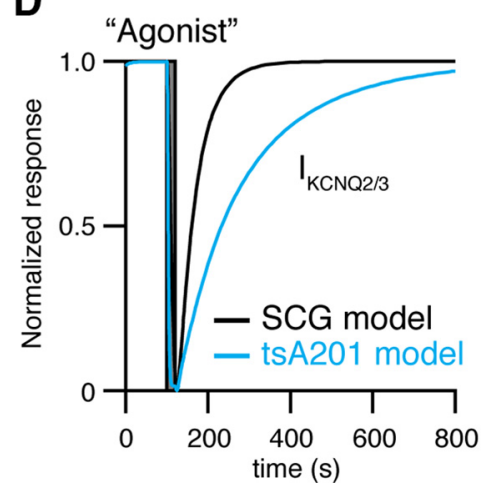

Figure 7. Summary comparison of modeled phosphoinositide metabolism and signaling in SCG neurons and tsA201 cells. $A$, Modeled time courses of $I_{3}$ in $S C G$ neurons and tsA201 cells in response to a 20 s long $10 \mu \mathrm{m} 0 \mathrm{xo}-\mathrm{M}$ application. $\boldsymbol{B}-\boldsymbol{D}$, As in $\boldsymbol{A}$, but for DAG $(\boldsymbol{B}), \mathrm{PI}(4,5) \mathrm{P}_{2}(\boldsymbol{C})$, and $\mathrm{K}_{\mathrm{KCNQ} / 3}(\boldsymbol{D})$.

\section{Discussion}

\section{$\mathrm{PI}(4) \mathrm{P}$ replenishment is fast in SCG neurons}

We found that $\mathrm{PI}(4) \mathrm{P}$, the $\mathrm{PI}(4,5) \mathrm{P}_{2}$ precursor, is restored faster in SCG neurons than in tsA201 cells. Because the PI pool is not larger, the most obvious explanation is that the enzymatic activity of the lipid 4-kinase is higher. The situation is subtle, because there are at least two sources of PI(4)P for $\mathrm{PI}(4,5) \mathrm{P}_{2}$ synthesis, the PM and the Golgi. In tsA201 cells, 70\% of $\mathrm{PI}(4,5) \mathrm{P}_{2}$ is synthesized from the $\mathrm{PI}(4) \mathrm{P}$ pool at the $\mathrm{PM}$, and the remaining $30 \%$ of $\mathrm{PI}(4,5) \mathrm{P}_{2}$ is synthesized from the pool at the Golgi (Dickson et al., 2014). Our model, which neglects the presence of two cellular compartments, predicts a fourfold faster PI(4)P synthesis than in tsA201 cells, in close agreement with the threefold increase in the rate of recovery measured experimentally. Our experimental setup allows us to measure PI(4)P recovery at the PM but does not allow us to discriminate between synthesis of PI(4)P from PI at the PM or delivery of PI(4)P from an intracellular compartment. Refined experimental designs will be necessary to analyze these processes in greater detail as studies have described mechanisms for an acceleration of lipid 4-kinases, as well as an important role for PI transfer proteins in supporting restoration of PI(4)P levels as discussed below.

Several mechanisms might increase the activity of lipid 4-kinases in SCG neurons. General mechanisms include altered expression levels or posttranslational modifications. Other mechanisms depend on protein interaction for directed localization. One is palmitoylation acting on lipid 4-kinase type II (Barylko et al., 2009; Zhou et al., 2014). Others include interaction of the lipid 4-kinase type III with PKC (Xu et al., 2014), TMEM150 (Chung et al., 2015), or with neuronal calcium sensor 1 (Paterlini et al., 2000; Zhao et al., 2001). We do not yet know whether any of these might apply here.

Faster PI(4)P synthesis at the PM requires a sufficient supply of the precursor, PI. Recent studies demonstrate an important role for PI transfer proteins, such as Nir2 (or PITPNM1), Nir3, and PITPNC1, in supplying PI to the PM from the ER and, under certain conditions, Golgi (Hardie et al., 2001; Garner et al., 2012; Chang et al., 2013; Kim et al., 2013, 2015; Chang and Liou, 2015). These proteins facilitate the transfer of PI to the PM at ER-PM junctions, and monitor $\mathrm{PI}(4,5) \mathrm{P}_{2}$ depletion by binding to phosphatidic acid, which stimulates their recruitment to ER-PM junctions. These papers demonstrate an essential role of PI transfer proteins in $\mathrm{PI}(4,5) \mathrm{P}_{2}$ recovery after its depletion, whereas they and other studies found only minor contributions of Golgi $\mathrm{PI}(4) \mathrm{P}$ and vesicular transport for $\mathrm{PI}(4,5) \mathrm{P}_{2}$ replenishment (Szentpetery et al., 2010). Our concept of faster synthesis of PI(4)P at the PM might have to be extended to include faster transfer of phosphoinositides to the PM.

\section{Implications of fast $\mathrm{PI}(4,5) \mathrm{P}_{2}$ replenishment in neurons}

We used KCNQ2/3 channels as a tool to measure $\mathrm{PI}(4,5) \mathrm{P}_{2}$. Focusing on the role of these channels we can see the relevance of fast synthesis of $\mathrm{PI}(4,5) \mathrm{P}_{2}$ in excitable cells. KCNQ2/3 channels are the molecular determinant of M-current (Wang et al., 1998), which controls excitability in sympathetic and many central neurons (Brown and Adams, 1980; Marrion, 1997; Jentsch, 2000). Sympathetic neurons of the SCG receive cholinergic input from preganglionic neurons. Acetylcholine produces a fast and a slow response (Libet, 1964; Weight and Votava, 1970), with the slow response being mediated by activation of G-protein-coupled receptors that deplete $\mathrm{PI}(4,5) \mathrm{P}_{2}$ (Suh and Hille, 2002; Zhang et al., 2003). Thus, whereas $\mathrm{PI}(4,5) \mathrm{P}_{2}$ is depleted, $\mathrm{M}$-current is inhibited and neurons are more excitable. Our analysis demonstrates that it takes $\sim 40$ s for SCG neurons to resynthesize enough $\mathrm{PI}(4,5) \mathrm{P}_{2}$ to reactivate most KCNQ2/3 channels, thereby restoring the resting membrane potential, ending the elevated excitability, and ending action potential firing. If instead, $\mathrm{PI}(4,5) \mathrm{P}_{2}$ synthesis rates were as measured for nonexcitable tsA201 cells, elevated electrical activity of SCG neurons would last threefold to fourfold longer.

We have seen that phosphoinositide metabolism differs between SCG neurons and tsA201 cells. Are all neurons the same? Given the special needs of the nervous system, it is tempting to imagine that many neurons have faster phosphoinositide dynamics than nonexcitable cells. In sensory neurons and photoreceptors, for example, TRP and other channels require phosphoinositides (Rohacs, 2014; Hille et al., 2015), and therefore the speed of phosphoinositide restoration in these neurons controls the dynamic range for sensory input (Yadav et al., 2015). In the brain, modulatory areas control other brain areas by releasing neurotransmitters and hormones, such as acetylcholine, norepinephrine, or serotonin, acting on G-protein-coupled receptors 
A

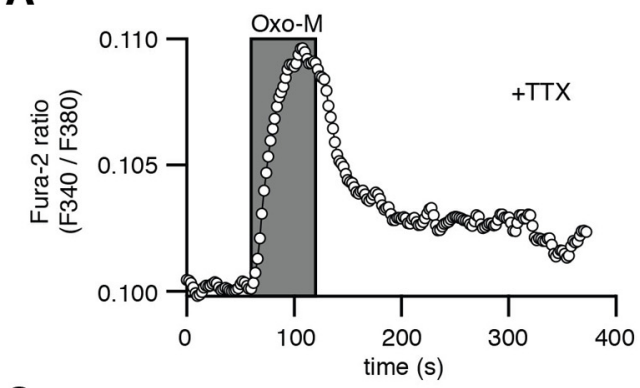

C

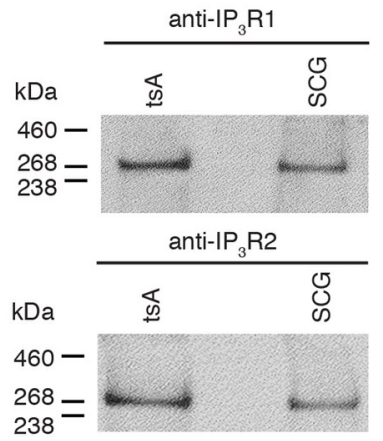

E

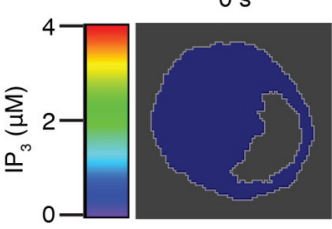

$6 s$
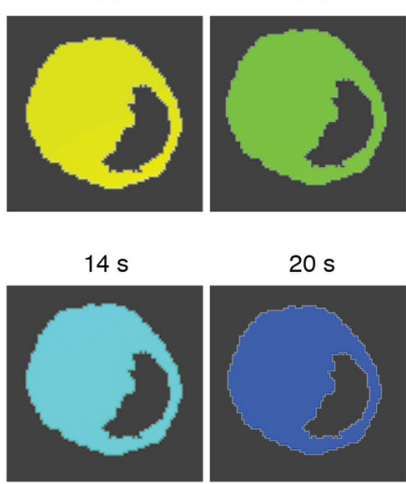

$20 \mathrm{~s}$
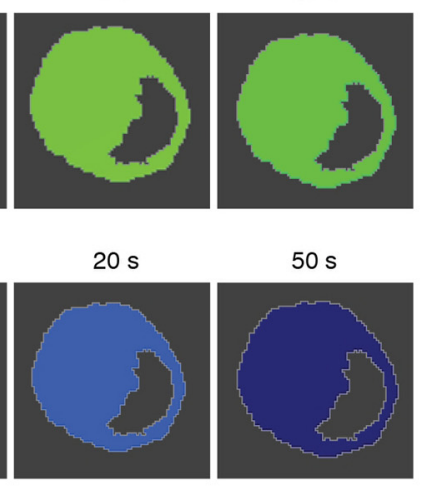

I

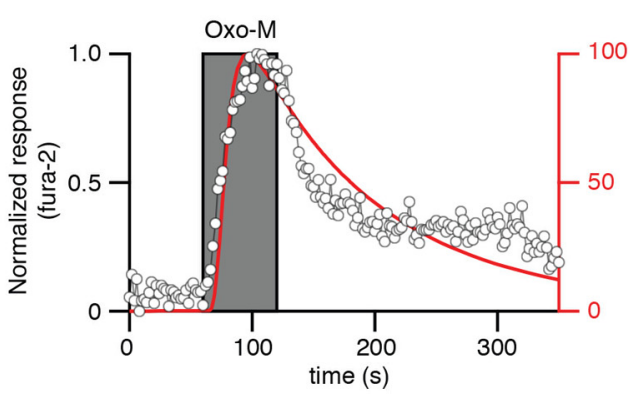

H

$\mathbf{F}$

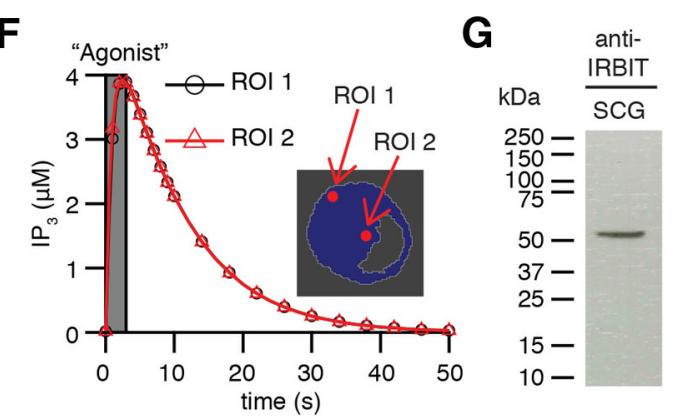

G
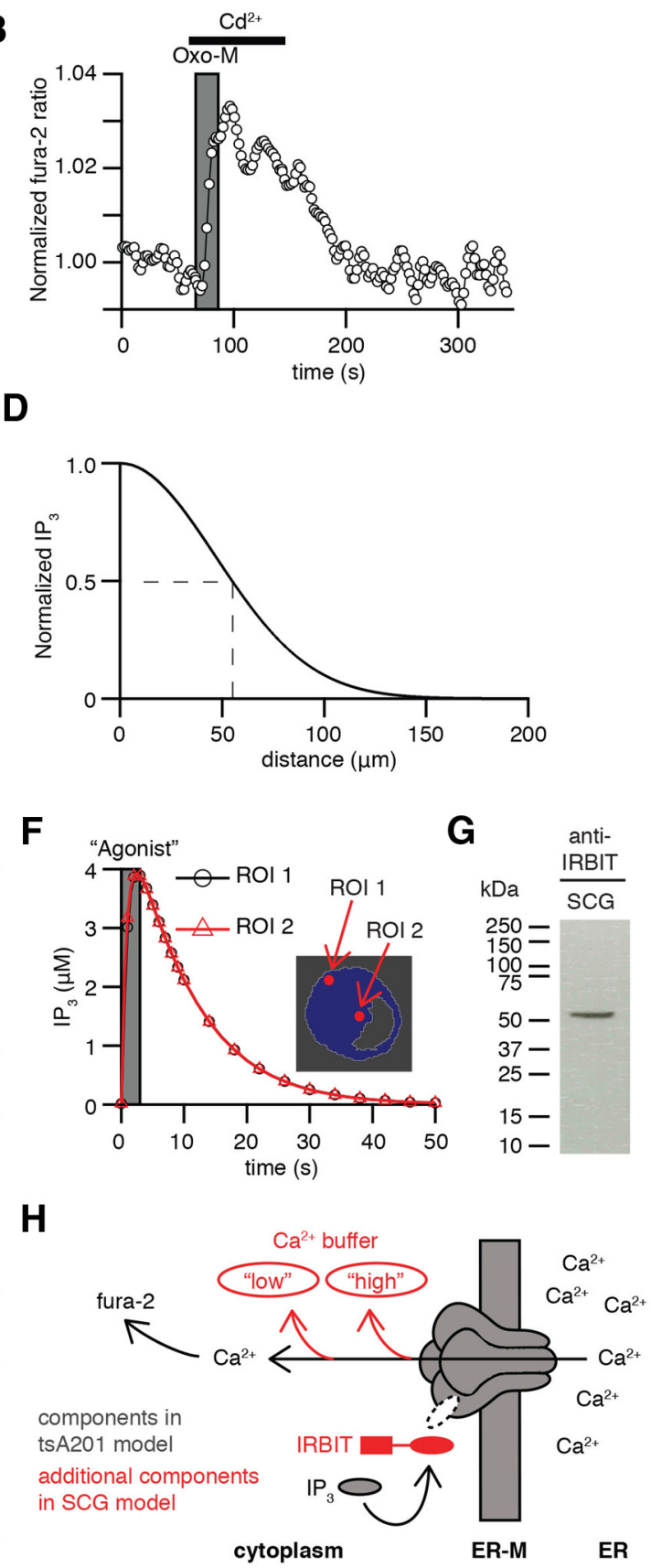

D
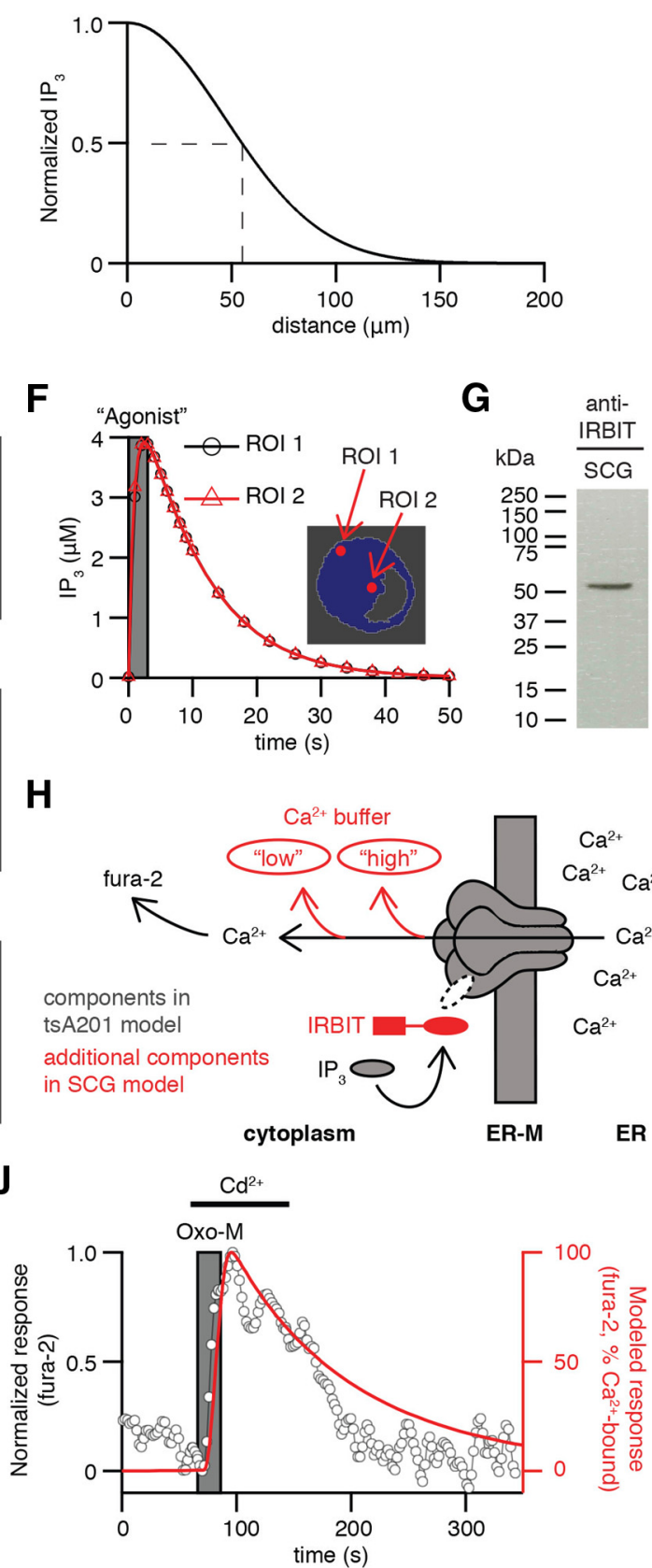

Figure 8. $\quad \mathrm{Ca}^{2+}$ signals after $\mathrm{M}_{1} \mathrm{R}$ activation in $\mathrm{SCG}$ neurons. $A$, Cytoplasmic $\mathrm{Ca}^{2+}$ in SCG neurons loaded with fura-2-AM and stimulated with $10 \mu \mathrm{M} 0 \mathrm{Oxo}-\mathrm{M}$. Fura-2 signals, measured in the presence of $100 \mathrm{~nm} \mathrm{TTX.} \mathrm{B,} \mathrm{Same} \mathrm{as} \mathrm{in} \mathrm{A,} \mathrm{but} \mathrm{with} 100 \mu \mathrm{M} \mathrm{CdCl}{ }_{2}$ as indicated instead of TTX. C, Western blot of membrane preparations of tsA201 cells and SCG neurons with anti-IP $\mathrm{R} 1$ (top left) and anti-IP $\mathrm{R} 2$ (bottom left) antibodies. Protein amounts of the samples were normalized for equal amounts. Right, Percentage of $I P_{3} R$ in $S C G$ neurons compared with tsA201 cells. Number in brackets indicates number of experiments. $\boldsymbol{D}$, Steady-state $\mathbb{I}_{3}$ profile in a two-dimensional model of the cytoplasm of a neuron. $\mathbb{P}_{3}$-production is assumed to occur at the origin. Concentrations at different

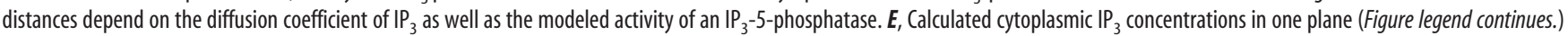


A

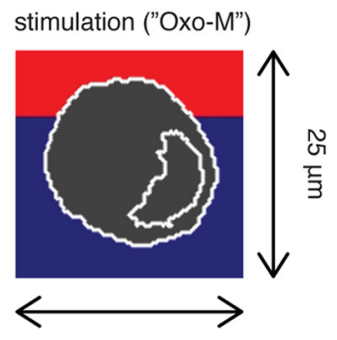

$25 \mu \mathrm{m}$

C

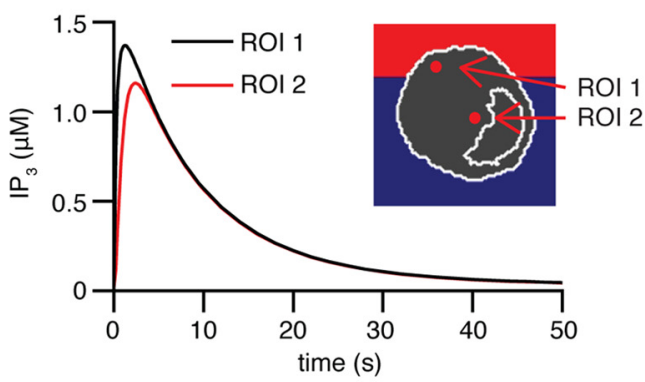

D

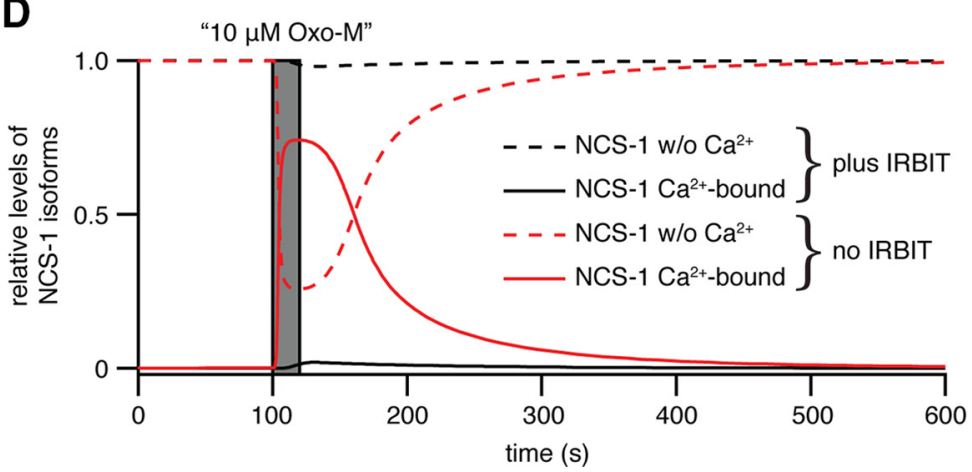

B

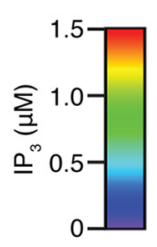

$0 \mathrm{~s}$

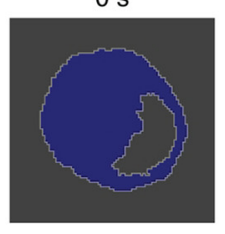

$1.8 \mathrm{~s}$

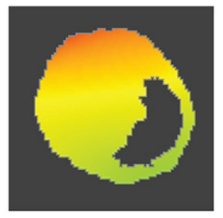

$4 \mathrm{~s}$
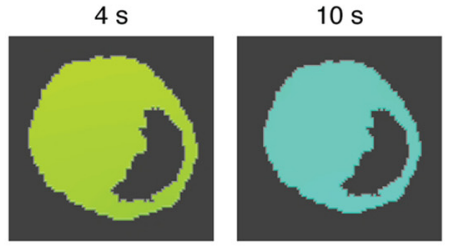

E

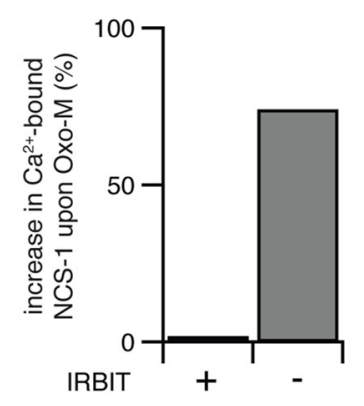

Figure 9. Gradients of $I P_{3}$ during local activation of $M_{1} R$ in a simulated $S C G$ neuron. $A$, The image shows one plane of a three-dimensional spatial model using the geometry of a $S C G$ neuron. Outlined are the plasma membrane as well as the nuclear membrane. The red field is the area in which the activating ligand $10 \mu \mathrm{m} 0 \mathrm{Oxo}-\mathrm{M}$ is present throughout the simulation. $\boldsymbol{B}$, Map of cytoplasmic $\mathbb{I P}_{3}$ concentrations for several time points during the simulation. The dark area inside the cytoplasm is the cell nucleus. $C$, Time course of $\mathbb{I P}_{3}$ concentrations for two regions-of-interest (ROI). Inset, Localization of ROIs. D, Simulated relative levels of $\mathrm{Ca}^{2+}$-bound and $\mathrm{Ca}^{2+}$-unbound NCS-1 isoforms in response to a simulated application of $10 \mu \mathrm{m} 0 \times 0$-M. Simulations were performed for presence (black) or absence (red) of IRBIT. $\boldsymbol{E}$, Simulated increase in $\mathrm{Ca}^{2+}$-bound NCS-1 upon muscarinic stimulation in the presence or absence of IRBIT.

that activate PLC and hydrolyze $\mathrm{PI}(4,5) \mathrm{P}_{2} . \mathrm{PI}(4,5) \mathrm{P}_{2}$-dependent $\mathrm{KCNQ} 2 / 3, \mathrm{Ca}_{\mathrm{V}} 2.2$, and $\mathrm{Ca}_{\mathrm{V}} 2.1$ channels are widely expressed in the brain, emphasizing the importance for rapid adjustment of phosphoinositide levels for coordinated ion channel activity in the brain.

$\mathrm{PI}(4,5) \mathrm{P}_{2}$ depletion in neuronal and cardiac tissues

Studies on isolated neurons provide strong evidence for net $\mathrm{PI}(4,5) \mathrm{P}_{2}$ depletion upon activation of muscarinic receptors,

$\leftarrow$

(Figure legend continued.) of a three-dimensional model of a SCG neuron upon uniform activation of $M_{1} R s$ for the indicated time on the cell surface with a saturating concentration of Oxo-M. $\boldsymbol{F}$, Calculated $\mathrm{IP}_{3}$ concentrations at two selected regions-of-interest (ROI) in the 3-D diffusion model in $\boldsymbol{E}$. $\boldsymbol{G}$, Western blot of lysate of SCG neurons with anti-IRBIT antibody. $\boldsymbol{H}$, Scheme of the components of the model involved in $\mathrm{Ca}^{2+}$-release from intracellular stores. Gray, Components included in tsA201 cell model; Red, additional components added in SCG model. $I$, Overlay of modeled fura- 2 response (red) on the time course of normalized fura- 2 signal evoked by stimulation of SCG neurons with $0 \times 0-M$ (black) in the presence of $100 \mathrm{~nm}$ TTX. $J$, Same as in $I$, but for simulation of fura-2 signal measured in the presence of $100 \mu \mathrm{M} \mathrm{CdCl}_{2}$ instead of TTX. leading to closure of $\mathrm{PI}(4,5) \mathrm{P}_{2}$-dependent ion channels such as KCNQ2/3 or $\mathrm{Ca}_{\mathrm{V}}$ channels in these cells (Suh and Hille, 2002; Gamper et al., 2004; Brown et al., 2007; Hughes et al., 2007; Zaika et al., 2007; Hille et al., 2015). However, it is not known to what extent natural stimuli cause net $\mathrm{PI}(4,5) \mathrm{P}_{2}$ depletion in intact neuronal tissues. Our simulations show that even a density of $<20$ $\mathrm{M}_{1} \mathrm{R} / \mu \mathrm{m}^{2}$ is sufficient to cause net $\mathrm{PI}(4,5) \mathrm{P}_{2}$ depletion at low agonist concentrations and to modulate KCNQ2/3 channel activity. Thus our simulations support the concept that even short exposure to low concentrations of agonists can cause net $\mathrm{PI}(4,5) \mathrm{P}_{2}$ depletion in intact neuronal tissues.

In contrast to studies on neurons, studies on cardiac cells have failed to reveal evidence for net $\mathrm{PI}(4,5) \mathrm{P}_{2}$ depletion, although the cells express $\mathrm{PI}(4,5) \mathrm{P}_{2}$-dependent ion channels and PLCactivating G-protein-coupled receptors (Gertjegerdes et al., 1979; Cho et al., 2002; Nasuhoglu et al., 2002; Hilgemann, 2007). It has been shown that cardiac cells respond to activation of certain $\mathrm{G} \alpha_{\mathrm{q}}$-coupled receptors with a slight increase in $\mathrm{PI}(4,5) \mathrm{P}_{2}$ levels, which mechanistically has been explained by enhanced activities of lipid 4- and 5-kinases upon activation of protein kinase C downstream of PLC activation (Xu et al., 2014). These temporally 
increased lipid kinase activities ensure the uninterrupted activity of $\mathrm{PI}(4,5) \mathrm{P}_{2}$-dependent ion channels. This stimulated $\mathrm{PI}(4,5) \mathrm{P}_{2}$ synthesis becomes understandable if one takes into account that the two main repolarizing potassium currents in the human heart, $\mathrm{I}_{\mathrm{Kr}}$ and $\mathrm{I}_{\mathrm{Ks}}$, are conducted by the $\mathrm{PI}(4,5) \mathrm{P}_{2}$-dependent Herg and KCNQ1/KCNE1 channel complexes (Charpentier et al., 2010; Vandenberg et al., 2012). Any reduction in the activity of these ion channels could cause cardiac arrhythmias or even sudden death, which makes it necessary to remain sufficiently high PI $(4,5) \mathrm{P}_{2}$ levels in cardiac cells. This situation is different for neuronal cells, which can use net $\mathrm{PI}(4,5) \mathrm{P}_{2}$ depletion as a mechanism to regulate ion channels and hereby neuronal activity. Perhaps in heart, the synthesis of phosphoinositides is significantly faster than in neurons or the maximum activity of PLC is significantly less.

\section{Uncoupling of $\mathrm{Ca}^{2+}$ release and $\mathrm{PI}(4,5) \mathrm{P}_{2}$ hydrolysis}

Most cell types respond to elevated levels of $\mathrm{IP}_{3}$ by increases in cytoplasmic $\mathrm{Ca}^{2+}$ concentrations in the micromolar range via release of $\mathrm{Ca}^{2+}$ from intracellular stores (Berridge, 2009). It has been shown that activation of purinergic and bradykinin receptors in SCG neurons causes significant release of $\mathrm{Ca}^{2+}$ from intracellular stores, but does not cause net $\mathrm{PI}(4,5) \mathrm{P}_{2}$ depletion (Zaika et al., 2007, 2011; Zhang et al., 2013). Activation of $\mathrm{M}_{1}$ receptors on the other hand causes net $\mathrm{PI}(4,5) \mathrm{P}_{2}$ depletion, but circumvents $\mathrm{Ca}^{2+}$ release from intracellular stores despite substantial $\mathrm{IP}_{3}$ generation as shown in this and previous studies (Zaika et al., 2007, 2011). Although all of these receptors are coupled to the small G-protein $\mathrm{G} \alpha_{\mathrm{q}}$ and activate PLC upon binding of their ligand, the subsequently activated signaling pathways are different. It is an interesting hypothesis that a protein like IRBIT could be a differentiating factor for the type of signals evoked by activation of these different receptors. It has been shown that bradykinin receptors physically interact with $\mathrm{IP}_{3}$ receptors while $\mathrm{M}_{1}$ receptors lack this interaction (Delmas et al., 2002; Zhang et al., 2013). One could speculate that the physical interaction between bradykinin and $\mathrm{IP}_{3}$ receptors prevents the interaction of IRBIT with $\mathrm{IP}_{3} \mathrm{Rs}$, which would create a pool of IRBIT-free $\mathrm{IP}_{3}$ receptors upon activation of bradykinin receptors. This receptor pool would then be available for $\mathrm{IP}_{3}$ to evoke a larger cytoplasmic $\mathrm{Ca}^{2+}$ increase compared with IRBITrestricted muscarinic stimulation as reported by several studies (Gamper and Shapiro, 2003; Zaika et al., 2011). A similar mechanism might be present for purinergic receptors for which a similarly large increase in cytoplasmic $\mathrm{Ca}^{2+}$ has been reported as for stimulation with bradykinin (Zaika et al., 2011). The differentiated response to PLC-activating stimuli could be a mechanism for SCG neurons to react combinatorially to incoming signals. In comparison, tsA201 cells lack this property as activation of PLC by any $\mathrm{G} \alpha_{\mathrm{q}}$-coupled receptor evokes release of $\mathrm{Ca}^{2+}$ from intracellular stores (Dickson et al., 2013). Apparently, neurons have a more nuanced response.

\section{References}

Allbritton NL, Meyer T, Stryer L (1992) Range of messenger action of calcium ion and inositol 1,4,5-trisphosphate. Science 258:1812-1815. CrossRef Medline

Ando H, Mizutani A, Matsu-ura T, Mikoshiba K (2003) IRBIT, a novel inositol 1,4,5-trisphosphate $\left(\mathrm{IP}_{3}\right)$ receptor-binding protein, is released from the $\mathrm{IP}_{3}$ receptor upon $\mathrm{IP}_{3}$ binding to the receptor. J Biol Chem 278:10602-10612. CrossRef Medline

Ando H, Mizutani A, Kiefer H, Tsuzurugi D, Michikawa T, Mikoshiba K (2006) IRBIT suppresses $\mathrm{IP}_{3}$ receptor activity by competing with $\mathrm{IP}_{3}$ for the common binding site on the $\mathrm{IP}_{3}$ receptor. Mol Cell 22:795-806. CrossRef Medline
Aravind P, Chandra K, Reddy PP, Jeromin A, Chary KV, Sharma Y (2008) Regulatory and structural EF-hand motifs of neuronal calcium sensor-1: $\mathrm{Mg}^{2+}$ modulates $\mathrm{Ca}^{2+}$ binding, $\mathrm{Ca}^{2+}$-induced conformational changes, and equilibrium unfolding transitions. J Mol Biol 376:1100-1115. CrossRef Medline

Barylko B, Mao YS, Wlodarski P, Jung G, Binns DD, Sun HQ, Yin HL, Albanesi JP (2009) Palmitoylation controls the catalytic activity and subcellular distribution of phosphatidylinositol 4-kinase II $\alpha$. J Biol Chem 284:9994-10003. CrossRef Medline

Beech DJ, Bernheim L, Mathie A, Hille B (1991) Intracellular $\mathrm{Ca}^{2+}$ buffers disrupt muscarinic suppression of $\mathrm{Ca}^{2+}$ current and $\mathrm{M}$ current in rat sympathetic neurons. Proc Natl Acad Sci U S A 88:652-656. CrossRef Medline

Berridge MJ (2009) Inositol trisphosphate and calcium signalling mechanisms. Biochim Biophys Acta 1793:933-940. CrossRef Medline

Berridge MJ, Irvine RF (1984) Inositol trisphosphate, a novel second messenger in cellular signal transduction. Nature 312:315-321. CrossRef Medline

Bezprozvanny I, Watras J, Ehrlich BE (1991) Bell-shaped calcium-response curves of $\operatorname{Ins}(1,4,5) \mathrm{P}_{3}-$ and calcium-gated channels from endoplasmic reticulum of cerebellum. Nature 351:751-754. CrossRef Medline

Brown DA, Adams PR (1980) Muscarinic suppression of a novel voltagesensitive $\mathrm{K}^{+}$current in a vertebrate neurone. Nature 283:673-676. CrossRef Medline

Brown DA, Passmore GM (2009) Neural KCNQ $\left(\mathrm{K}_{\mathrm{V}} 7\right)$ channels. Br J Pharmacol 156:1185-1195. CrossRef Medline

Brown DA, Hughes SA, Marsh SJ, Tinker A (2007) Regulation of $\mathrm{M}\left(\mathrm{K}_{\mathrm{V}} 7.2 /\right.$ 7.3) channels in neurons by $\mathrm{PIP}_{2}$ and products of $\mathrm{PIP}_{2}$ hydrolysis: significance for receptor-mediated inhibition. J Physiol 582:917-925. CrossRef Medline

Cantley LC (2002) The phosphoinositide 3-kinase pathway. Science 296: 1655-1657. CrossRef Medline

Chang CL, Liou J (2015) Phosphatidylinositol 4,5-bisphosphate homeostasis regulated by Nir2 and Nir3 proteins at endoplasmic reticulum-plasma membrane junctions. J Biol Chem 290:14289-14301. CrossRef Medline

Chang CL, Hsieh TS, Yang TT, Rothberg KG, Azizoglu DB, Volk E, Liao JC, Liou J (2013) Feedback regulation of receptor-induced $\mathrm{Ca}^{2+}$ signaling mediated by E-Syt1 and Nir2 at endoplasmic reticulum-plasma membrane junctions. Cell Rep 5:813-825. CrossRef Medline

Charpentier F, Mérot J, Loussouarn G, Baró I (2010) Delayed rectifier K ${ }^{+}$ currents and cardiac repolarization. J Mol Cell Cardiol 48:37-44. CrossRef Medline

Cho H, Hwang JY, Kim D, Shin HS, Kim Y, Earm YE, Ho WK (2002) Acetylcholine-induced phosphatidylinositol 4,5-bisphosphate depletion does not cause short-term desensitization of $\mathrm{G}$ protein-gated inwardly rectifying $\mathrm{K}^{+}$current in mouse atrial myocytes. J Biol Chem 277:2774227747. CrossRef Medline

Chung J, Nakatsu F, Baskin JM, De Camilli P (2015) Plasticity of PI4KIII $\alpha$ interactions at the plasma membrane. EMBO Rep 16:312-320. CrossRef Medline

Clark J, Anderson KE, Juvin V, Smith TS, Karpe F, Wakelam MJ, Stephens LR, Hawkins PT (2011) Quantification of PtdInsP $P_{3}$ molecular species in cells and tissues by mass spectrometry. Nat Methods 8:267-272. CrossRef Medline

Cremona O, De Camilli P (2001) Phosphoinositides in membrane traffic at the synapse. J Cell Sci 114:1041-1052. Medline

Cruzblanca H, Koh DS, Hille B (1998) Bradykinin inhibits M current via phospholipase $\mathrm{C}$ and $\mathrm{Ca}^{2+}$ release from $\mathrm{IP}_{3}$-sensitive $\mathrm{Ca}^{2+}$ stores in rat sympathetic neurons. Proc Natl Acad Sci U S A 95:7151-7156. CrossRef Medline

del Río E, Bevilacqua JA, Marsh SJ, Halley P, Caulfield MP (1999) Muscarinic $\mathrm{M}_{1}$ receptors activate phosphoinositide turnover and $\mathrm{Ca}^{2+}$ mobilisation in rat sympathetic neurones, but this signalling pathway does not mediate M-current inhibition. J Physiol 520:101-111. CrossRef Medline

Delmas P, Wanaverbecq N, Abogadie FC, Mistry M, Brown DA (2002) Signaling microdomains define the specificity of receptor-mediated $\mathrm{Ins}_{3}$ pathways in neurons. Neuron 34:209-220. CrossRef Medline

Dickson EJ, Falkenburger BH, Hille B (2013) Quantitative properties and receptor reserve of the $\mathrm{IP}_{3}$ and calcium branch of $\mathrm{G}_{\mathrm{q}}$-coupled receptor signaling. J Gen Physiol 141:521-535. CrossRef Medline

Dickson EJ, Jensen JB, Hille B (2014) Golgi and plasma membrane pools of $\mathrm{PI}(4) \mathrm{P}$ contribute to plasma membrane $\mathrm{PI}(4,5) \mathrm{P}_{2}$ and maintenance of 
KCNQ2/3 ion channel current. Proc Natl Acad Sci U S A 111:E2281E2290. CrossRef Medline

Di Paolo G, De Camilli P (2006) Phosphoinositides in cell regulation and membrane dynamics. Nature 443:651-657. CrossRef Medline

Duman JG, Chen L, Hille B (2008) Calcium transport mechanisms of PC12 cells. J Gen Physiol 131:307-323. CrossRef Medline

Falkenburger BH, Jensen JB, Hille B (2010a) Kinetics of $M_{1}$ muscarinic receptor and $\mathrm{G}$ protein signaling to phospholipase $\mathrm{C}$ in living cells. J Gen Physiol 135:81-97. CrossRef Medline

Falkenburger BH, Jensen JB, Hille B (2010b) Kinetics of $\mathrm{PIP}_{2}$ metabolism and KCNQ2/3 channel regulation studied with a voltage-sensitive phosphatase in living cells. J Gen Physiol 135:99-114. CrossRef Medline

Falkenburger BH, Dickson EJ, Hille B (2013) Quantitative properties and receptor reserve of the DAG and PKC branch of $\mathrm{G}_{\mathrm{q}}$-coupled receptor signaling. J Gen Physiol 141:537-555. CrossRef Medline

Gamper N, Shapiro MS (2003) Calmodulin mediates $\mathrm{Ca}^{2+}$-dependent modulation of M-type $\mathrm{K}^{+}$channels. J Gen Physiol 122:17-31. CrossRef Medline

Gamper N, Reznikov V, Yamada Y, Yang J, Shapiro MS (2004) Phosphatidylinositol 4,5-bisphosphate signals underlie receptor-specific $\mathrm{G}_{\mathrm{q} / 11}$-mediated modulation of N-type $\mathrm{Ca}^{2+}$ channels. J Neurosci 24:10980-10992. CrossRef Medline

Garner K, Hunt AN, Koster G, Somerharju P, Groves E, Li M, Raghu P, Holic R, Cockcroft S (2012) Phosphatidylinositol transfer protein, cytoplasmic 1 (PITPNC1) binds and transfers phosphatidic acid. J Biol Chem 287:32263-32276. CrossRef Medline

Gertjegerdes W, Ravens U, Ziegler A (1979) Time courses of carbacholinduced responses in guinea pig atria under the influence of ouabain, calcium, and rate of stimulation. J Cardiovasc Pharmacol 1:235-243. CrossRef Medline

Hammond GR, Machner MP, Balla T (2014) A novel probe for phosphatidylinositol 4-phosphate reveals multiple pools beyond the Golgi. J Cell Biol 205:113-126. CrossRef Medline

Hardie RC, Raghu P, Moore S, Juusola M, Baines RA, Sweeney ST (2001) Calcium influx via TRP channels is required to maintain PIP $_{2}$ levels in Drosophila photoreceptors. Neuron 30:149-159. CrossRef Medline

Hilgemann DW (2007) On the physiological roles of $\mathrm{PIP}_{2}$ at cardiac $\mathrm{Na}^{+}$ $\mathrm{Ca}^{2+}$ exchangers and $\mathrm{K}_{\mathrm{ATP}}$ channels: a long journey from membrane biophysics into cell biology. J Physiol 582:903-909. CrossRef Medline

Hille B, Dickson EJ, Kruse M, Vivas O, Suh BC (2015) Phosphoinositides regulate ion channels. Biochim Biophys Acta 1851:844-856. CrossRef Medline

Hughes S, Marsh SJ, Tinker A, Brown DA (2007) PIP 2 -dependent inhibition of M-type $\left(\mathrm{K}_{\mathrm{V}}\right.$ 7.2/7.3) potassium channels: direct on-line assessment of $\mathrm{PIP}_{2}$ depletion by $\mathrm{G}_{\mathrm{q}}$-coupled receptors in single living neurons. Pflugers Arch 455:115-124. CrossRef Medline

Ichikawa H, Terayama R, Yamaai T, Sugimoto T (2009) Peptide 19 in the rat superior cervical ganglion. Neuroscience 161:86-94. CrossRef Medline

Itsuki K, Imai Y, Hase H, Okamura Y, Inoue R, Mori MX (2014) PLCmediated $\mathrm{PI}(4,5) \mathrm{P}_{2}$ hydrolysis regulates activation and inactivation of TRPC6/7 channels. J Gen Physiol 143:183-201. CrossRef Medline

Jacobowitz D, Woodward JK (1968) Adrenergic neurons in the cat superior cervical ganglion and cervical sympathetic nerve trunk: a histochemical study. J Pharmacol Exp Ther 162:213-226. Medline

Jensen JB, Lyssand JS, Hague C, Hille B (2009) Fluorescence changes reveal kinetic steps of muscarinic receptor-mediated modulation of phosphoinositides and $\mathrm{K}_{\mathrm{V}}$ 7.2/7.3 $\mathrm{K}^{+}$channels. J Gen Physiol 133: 347-359. CrossRef Medline

Jentsch TJ (2000) Neuronal KCNQ potassium channels: physiology and role in disease. Nat Rev Neurosci 1:21-30. CrossRef Medline

Ke XX, Zhang D, Zhao H, Hu R, Dong Z, Yang R, Zhu S, Xia Q, Ding HF, Cui $\mathrm{H}$ (2015) Phox2B correlates with MYCN and is a prognostic marker for neuroblastoma development. Oncol Lett 9:2507-2514. CrossRef Medline

Kim S, Kedan A, Marom M, Gavert N, Keinan O, Selitrennik M, Laufman O, Lev S (2013) The phosphatidylinositol-transfer protein Nir2 binds phosphatidic acid and positively regulates phosphoinositide signalling. EMBO Rep 14:891-899. CrossRef Medline

Kim YJ, Guzman-Hernandez ML, Wisniewski E, Balla T (2015) Phosphatidylinositol-phosphatidic acid exchange by Nir2 at ER-PM contact sites maintains phosphoinositide signaling competence. Dev Cell 33:549561. CrossRef Medline

Laketa V, Zarbakhsh S, Traynor-Kaplan A, Macnamara A, Subramanian D,
Putyrski M, Mueller R, Nadler A, Mentel M, Saez-Rodriguez J, Pepperkok $\mathrm{R}$, Schultz C (2014) PIP $_{3}$ induces the recycling of receptor tyrosine kinases. Sci Signal 7:ra5. CrossRef Medline

Libet B (1964) Slow synaptic responses and excitatory changes in sympathetic ganglia. J Physiol 174:1-25. CrossRef Medline

Marrion NV (1997) Control of M-current. Annu Rev Physiol 59:483-504. CrossRef Medline

Martin TF (2015) PI(4,5) $\mathrm{P}_{2}$-binding effector proteins for vesicle exocytosis. Biochim Biophys Acta 1851:785-793. CrossRef Medline

Michell RH (1975) Inositol phospholipids and cell surface receptor function. Biochim Biophys Acta 415:81-147. CrossRef Medline

Micheva KD, Holz RW, Smith SJ (2001) Regulation of presynaptic phosphatidylinositol 4,5-biphosphate by neuronal activity. J Cell Biol 154: 355-368. CrossRef Medline

Murata Y, Okamura Y (2007) Depolarization activates the phosphoinositide phosphatase Ci-VSP, as detected in Xenopus oocytes coexpressing sensors of PIP 2 . J Physiol 583:875-889. CrossRef Medline

Nasuhoglu C, Feng S, Mao Y, Shammat I, Yamamato M, Earnest S, Lemmon M, Hilgemann DW (2002) Modulation of cardiac PIP $_{2}$ by cardioactive hormones and other physiologically relevant interventions. Am J Physiol Cell Physiol 283:C223-234. CrossRef Medline

Paterlini M, Revilla V, Grant AL, Wisden W (2000) Expression of the neuronal calcium sensor protein family in the rat brain. Neuroscience 99: 205-216. CrossRef Medline

Pawson AJ, Sharman JL, Benson HE, Faccenda E, Alexander SP, Buneman OP, Davenport AP, McGrath JC, Peters JA, Southan C, Spedding M, Yu W, Harmar AJ; NC-IUPHAR (2014) The IUPHAR/BPS guide to pharmacology: an expert-driven knowledgebase of drug targets and their ligands. Nucleic Acids Res 42:D1098-1106. CrossRef Medline

Posor Y, Eichhorn-Grünig M, Haucke V (2015) Phosphoinositides in endocytosis. Biochim Biophys Acta 1851:794-804. CrossRef Medline

Rajebhosale M, Greenwood S, Vidugiriene J, Jeromin A, Hilfiker S (2003) Phosphatidylinositol 4-OH kinase is a downstream target of neuronal calcium sensor-1 in enhancing exocytosis in neuroendocrine cells. J Biol Chem 278:6075-6084. CrossRef Medline

Rohacs T (2014) Phosphoinositide regulation of TRP channels. Handb Exp Pharmacol 223:1143-1176. CrossRef Medline

Saarikangas J, Zhao H, Lappalainen P (2010) Regulation of the actin cytoskeleton-plasma membrane interplay by phosphoinositides. Physiol Rev 90:259-289. CrossRef Medline

Strahl T, Grafelmann B, Dannenberg J, Thorner J, Pongs O (2003) Conservation of regulatory function in calcium-binding proteins: human frequenin (neuronal calcium sensor-1) associates productively with yeast phosphatidylinositol 4-kinase isoform, Pik1. J Biol Chem 278:49589_ 49599. CrossRef Medline

Suh BC, Hille B (2002) Recovery from muscarinic modulation of M current channels requires phosphatidylinositol 4,5-bisphosphate synthesis. Neuron 35:507-520. CrossRef Medline

Szentpetery Z, Várnai P, Balla T (2010) Acute manipulation of Golgi phosphoinositides to assess their importance in cellular trafficking and signaling. Proc Natl Acad Sci U S A 107:8225-8230. CrossRef Medline

Tanimura A, Morita T, Nezu A, Shitara A, Hashimoto N, Tojyo Y (2009) Use of fluorescence resonance energy transfer-based biosensors for the quantitative analysis of inositol 1,4,5-trisphosphate dynamics in calcium oscillations. J Biol Chem 284:8910-8917. CrossRef Medline

Vandenberg JI, Perry MD, Perrin MJ, Mann SA, Ke Y, Hill AP (2012) hERG $\mathrm{K}^{+}$channels: structure, function, and clinical significance. Physiol Rev 92:1393-1478. CrossRef Medline

Vivas O, Castro H, Arenas I, Elías-Viñas D, García DE (2013) PIP ${ }_{2}$ hydrolysis is responsible for voltage independent inhibition of $\mathrm{Ca}_{\mathrm{v}} 2.2$ channels in sympathetic neurons. Biochem Biophys Res Commun 432:275-280. CrossRef Medline

Vivas O, Kruse M, Hille B (2014) Nerve growth factor sensitizes adult sympathetic neurons to the proinflammatory peptide bradykinin. J Neurosci 34:11959-11971. CrossRef Medline

Wanaverbecq N, Marsh SJ, Al-Qatari M, Brown DA (2003) The plasma membrane calcium-ATPase as a major mechanism for intracellular calcium regulation in neurones from the rat superior cervical ganglion. J Physiol 550:83-101. CrossRef Medline

Wang HS, Pan Z, Shi W, Brown BS, Wymore RS, Cohen IS, Dixon JE, McKinnon D (1998) KCNQ2 and KCNQ3 potassium channel subunits: 
molecular correlates of the M-channel. Science 282:1890-1893. CrossRef Medline

Weight FF, Votava J (1970) Slow synaptic excitation in sympathetic ganglion cells: evidence for synaptic inactivation of potassium conductance. Science 170:755-758. CrossRef Medline

Willars GB, Nahorski SR, Challiss RA (1998) Differential regulation of muscarinic acetylcholine receptor-sensitive polyphosphoinositide pools and consequences for signaling in human neuroblastoma cells. J Biol Chem 273:5037-5046. CrossRef Medline

Winks JS, Hughes S, Filippov AK, Tatulian L, Abogadie FC, Brown DA, Marsh SJ (2005) Relationship between membrane phosphatidylinositol-4,5bisphosphate and receptor-mediated inhibition of native neuronal $\mathrm{M}$ channels. J Neurosci 25:3400-3413. CrossRef Medline

Xu C, Watras J, Loew LM (2003) Kinetic analysis of receptor-activated phosphoinositide turnover. J Cell Biol 161:779-791. CrossRef Medline

Xu JX, Si M, Zhang HR, Chen XJ, Zhang XD, Wang C, Du XN, Zhang HL (2014) Phosphoinositide kinases play key roles in norepinephrine- and angiotensin II-induced increase in phosphatidylinositol 4,5-bisphosphate and modulation of cardiac function. J Biol Chem 289:6941-6948. CrossRef Medline

Yadav S, Garner K, Georgiev P, Li M, Gomez-Espinosa E, Panda A, Mathre S, Okkenhaug H, Cockcroft S, Raghu P (2015) RDGB $\alpha$, a PtdIns-PtdOH transfer protein, regulates G-protein-coupled $\operatorname{PtdIns}(4,5) \mathrm{P}_{2}$ signalling during Drosophila phototransduction. J Cell Sci 128:3330-3344. CrossRef Medline

Zaika O, Tolstykh GP, Jaffe DB, Shapiro MS (2007) Inositol triphosphatemediated $\mathrm{Ca}^{2+}$ signals direct purinergic $\mathrm{P} 2 \mathrm{Y}$ receptor regulation of neuronal ion channels. J Neurosci 27:8914-8926. CrossRef Medline

Zaika O, Zhang J, Shapiro MS (2011) Combined phosphoinositide and $\mathrm{Ca}^{2+}$ signals mediating receptor specificity toward neuronal $\mathrm{Ca}^{2+}$ channels. J Biol Chem 286:830-841. CrossRef Medline

Zhang H, Craciun LC, Mirshahi T, Rohács T, Lopes CM, Jin T, Logothetis DE (2003) PIP $_{2}$ activates KCNQ channels, and its hydrolysis underlies receptor-mediated inhibition of $\mathrm{M}$ currents. Neuron 37:963-975. CrossRef Medline

Zhang H, Liu Y, Xu J, Zhang F, Liang H, Du X, Zhang H (2013) Membrane microdomain determines the specificity of receptor-mediated modulation of $\mathrm{K}_{\mathrm{V}} 7 / \mathrm{M}$ potassium currents. Neuroscience 254:70-79. CrossRef Medline

Zhao X, Várnai P, Tuymetova G, Balla A, Tóth ZE, Oker-Blom C, Roder J, Jeromin A, Balla T (2001) Interaction of neuronal calcium sensor-1 (NCS-1) with phosphatidylinositol 4-kinase $\beta$ stimulates lipid kinase activity and affects membrane trafficking in COS-7 cells. J Biol Chem 276: 40183-40189. CrossRef Medline

Zhou Q, Li J, Yu H, Zhai Y, Gao Z, Liu Y, Pang X, Zhang L, Schulten K, Sun F, Chen C (2014) Molecular insights into the membrane-associated phosphatidylinositol 4-kinase II $\alpha$. Nat Commun 5:3552. CrossRef Medline 